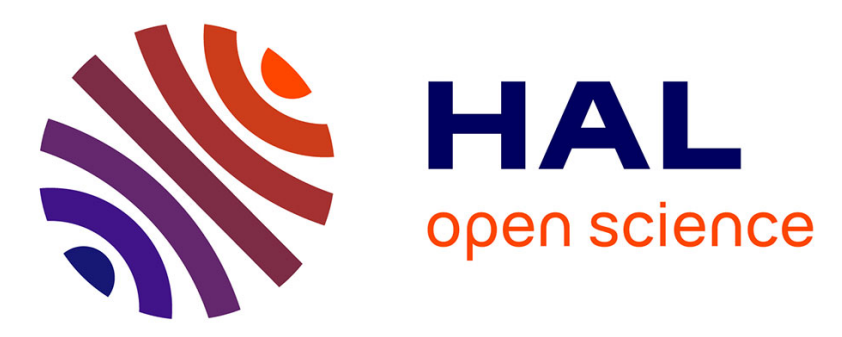

\title{
New insight into the molecular evolution of the somatostatin family
}

Hervé Tostivint, Isabelle Lihrmann, Hubert Vaudry

\section{To cite this version:}

Hervé Tostivint, Isabelle Lihrmann, Hubert Vaudry. New insight into the molecular evolution of the somatostatin family. Molecular and Cellular Endocrinology, 2008, 286 (1-2), pp.5-17. 10.1016/j.mce.2008.02.029 . hal-00532012

\section{HAL Id: hal-00532012 \\ https://hal.science/hal-00532012}

Submitted on 4 Nov 2010

HAL is a multi-disciplinary open access archive for the deposit and dissemination of scientific research documents, whether they are published or not. The documents may come from teaching and research institutions in France or abroad, or from public or private research centers.
L'archive ouverte pluridisciplinaire HAL, est destinée au dépôt et à la diffusion de documents scientifiques de niveau recherche, publiés ou non, émanant des établissements d'enseignement et de recherche français ou étrangers, des laboratoires publics ou privés. 


\section{Accepted Manuscript}

Title: New insight into the molecular evolution of the somatostatin family

Authors: Hervé Tostivint, Isabelle Lihrmann, Hubert Vaudry

PII: $\quad$ S0303-7207(08)00115-9

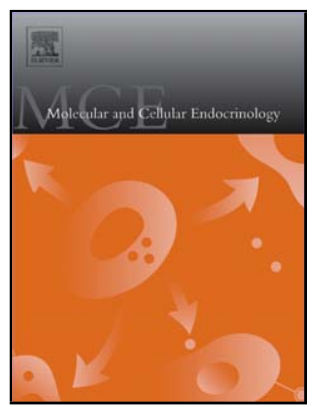

DOI: doi:10.1016/j.mce.2008.02.029

Reference: MCE 6840

To appear in: $\quad$ Molecular and Cellular Endocrinology

Received date: $\quad 1-6-2007$

Revised date: 26-2-2008

Accepted date: $\quad$ 28-2-2008

Please cite this article as: Tostivint, H., Lihrmann, I., Vaudry, H., New insight into the molecular evolution of the somatostatin family, Molecular and Cellular Endocrinology (2007), doi:10.1016/j.mce.2008.02.029

This is a PDF file of an unedited manuscript that has been accepted for publication. As a service to our customers we are providing this early version of the manuscript. The manuscript will undergo copyediting, typesetting, and review of the resulting proof before it is published in its final form. Please note that during the production process errors may be discovered which could affect the content, and all legal disclaimers that apply to the journal pertain. 
Molecular and Cellular

Endocrinology

Ms \# MCE-D-07-0125

Revised version

\title{
New insight into the molecular evolution of the somatostatin family
}

\author{
Hervé Tostivint $^{1,2}$, Isabelle Lihrmann ${ }^{1,2}$, Hubert Vaudry ${ }^{1,2 *}$ \\ ${ }^{1}$ INSERM U413, Laboratory of Cellular and Molecular Neuroendocrinology; \\ ${ }^{2}$ European Institute for Peptide Research (IFRMP 23), University of Rouen, \\ 76821 Mont-Saint-Aignan, France
}

* To whom correspondence should be addressed. Tel.: (33) 235-14-6624; Fax.: (33) 23514-6946; E-mail: hubert.vaudry@univ-rouen.fr 


\begin{abstract}
The present review describes the molecular evolution of the somatostatin family and its relationships with that of the urotensin II family. Most of the somatostatin sequences collected from different vertebrate species can be grouped as the products of at least four loci. The somatostatin 1 (SS1) gene is present in all vertebrate classes from agnathans to mammals. The SS1 gene has given rise to the somatostatin 2 (SS2) gene by a segment/chromosome duplication that is probably the result of a tetraploidization event according to the $2 \mathrm{R}$ hypothesis. The somatostatin-related peptide cortistatin, first identified in rodents and human, is the counterpart of SS2 in placental mammals. In fish, the existence of two additional somatostatin genes has been reported. The first gene, which encodes a peptide usually named somatostatin II (SSII), exists in almost all teleost species investigated so far and is thought to have arisen through local duplication of the SS1 gene. The second gene, which has been characterized in only a few teleost species, encodes a peptide also named SSII that exhibits a totally atypical structure. The origin of this gene is currently unknown. Nevertheless, because the two latter genes are clearly paralogous genes, we propose to rename them SS3 and SS4, respectively, in order to clarify the current confusing nomenclature. The urotensin II family consists of two genes, namely the urotensin II (UII) gene and the UII-related peptide (URP) gene. Both UII and URP exhibit limited structural identity to somatostatin so that UII was originally described as a "somatostatin-like peptide". Recent comparative genomics studies have revealed that the SS1 and URP genes, on the one hand, and the SS2 and UII genes, on the other hand, are closely linked on the same chromosomes, thus confirming that the SS1/SS2 and the UII/URP genes belong to the same superfamily. According to these data, it appears that an ancestral somatostatin/urotensin II gene gave rise by local duplication to a somatostatin ancestor and a urotensin II ancestor, whereupon this pair was duplicated (presumably by a segment/chromosome duplication) to give rise to the SS1-UII pair and the SS2-URP pair.
\end{abstract}


Keywords: somatostatin, urotensin II, cortistatin, neuropeptides, molecular evolution, multigenic families, gene duplication, comparative genomics.

Abbreviations: CRH, corticotropin-releasing hormone; CST, cortistatin; GRH, growth hormone-releasing hormone; NPY, neuropeptide tyrosine; PACAP, pituitary adenylate cyclase-activating polypeptide; PAMNT, proadrennomedullin N-terminal peptides; PCST, procortistatin; PSS, prosomatostatin; SS, somatostatin; SST, somatostatin receptor; UII, urotensin II; URP, urotensin II-related peptide; UT: UII/URP receptor; VIP, vasoactive intestinal polypeptide. 


\section{Content}

1. Introduction

2. Diversity of somatostatin-related peptides

2.1. Somatostatin 1

2.2. Somatostatin 2 / cortistatin

2.3. Teleost somatostatin variants

2.4. Other somatostatin variants

3. Origin of somatostatin-related peptide encoding genes

3.1. Somatostatin 1 gene

3.2 Somatostatin 2 / cortistatin gene

3.3. Teleost-specific somatostatin genes

3.4. Other somatostatin genes

4. Evolutionary relationships between somatostatin- and urotensin II-related peptides

5. Proposal for a new nomenclature of the somatostatin gene family

6. Concluding remarks

References 


\section{Introduction}

In vertebrates, most neuropeptides are members of multigene families that have extended by successive gene duplications (Conlon and Larhammar, 2005). Owing to the characteristic tokens that these duplication events have left in the genome, comparative genomics has now become a very powerful approach to trace back the phylogenetic history of multigene families (Van de Peer, 2004; Durand and Hoberman, 2006). Two types of gene duplications are generally distinguished: local duplications that implicate individual genes, and segmental duplications that involve chromosomal segments or even the entire genome (Van de Peer, 2004). Vertebrates are known to have undergone several rounds of whole genome duplications that took place very early during their history (Dehal and Boore, 2005), and the occurrence of a third tetraploidization event in the ancestral fish lineage has been recently demonstrated (Jaillon et al., 2004).

Somatostatin has long been viewed as the sole representative of its family, at least in tetrapods. However, numerous studies have subsequently shown that many (possibly all) vertebrates, including amphibians, reptiles, birds and mammals, have a family of somatostatin genes (Conlon et al., 1997a; Lin et al., 2000a; Tostivint et al., 2004a). The aim of the present review is to briefly describe the diversity of somatostatin-related peptides, to revisit the evolutionary history of this multigene family at the light of recent data provided by comparative genomics, and to propose a new nomenclature taking into account these data.

\section{Diversity of somatostatin-related peptides}

The neuropeptide somatostatin is a cyclic tetradecapeptide (SS-14) that has been initially identified from ovine hypothalamic extracts on the basis of its ability to inhibit growth hormone release (Brazeau et al., 1973). Since the original discovery of this peptide (later called somatostatin 1; SS1) several other somatostatin-related peptides have been characterized in various vertebrate species. All somatostatin variants exhibit a relatively well conserved structure with only a few variations in sequence and size. They possess a cyclic 
conformation ensured by the presence of two Cys residues, and their cyclic region encompasses the Phe-Trp-Lys motif that is essential for their biological activity (Veber et al., 1979). The somatostatin genes generally contain only one intron, located in the region encoding the cryptic domain, and the somatostatin peptides are all located at the C-terminal extremity of the precursors.

\subsection{Somatostatin 1}

Of all the structural variants of somatostatin, $\mathrm{SS} 1$ is the only one that is almost totally conserved and universally present in all vertebrate species (Fig. 1; Table 1). SS1 is widely distributed in the central nervous system where it affects locomotor, sensitive, autonomic and cognitive functions, as well as in various peripheral organs where it is involved in the control of the secretory activity and proliferation of a wide range of endocrine and exocrine cells (Olias et al., 2004). SS1 is synthesized as part of a larger precursor molecule, named preproSS1 (PSS1), which is also able to generate, notably in mammals, an N-terminally-extended form of 28 residues, called somatostatin-28 (SS-28; Fig. 1; Esch et al. 1980; Pradayrol et al., 1980). The two peptides SS1 and SS-28 are synthesized in variable amounts by distinct PSS1producing cells as a result of differential precursor processing. Thus, SS1 is most abundant in the brain, stomach and pancreas, while SS-28 predominates in the intestine. In mammals, the actions of SS1 are mediated via five somatostatin receptor subtypes $\left(\mathrm{SST}_{1-5}\right)$ which all belong to the G protein-coupled receptor superfamily (Møller et al., 2003; Olias et al., 2004). SS1 binds to all five subtypes with comparable potency, but the affinity of $\mathrm{SST}_{1-4}$ for SS1 is two to three times higher than for SS-28. In contrast, $\mathrm{SST}_{5}$ appears to preferentially bind SS28 than SS1 (Panetta et al., 1994; Patel et al., 1994). In fish, a total of four different SST subtypes have been characterized $\left(\mathrm{SST}_{1-3}, \mathrm{SST}_{5}\right)$. In goldfish and trout, several isoforms of these receptor subtypes have been identified (Lin et al., 1999a, 2000b, 2002; Lin and Peter 2003; Slagter and Sheridan, 2004). 


\subsection{Somatostatin 2 / cortistatin}

Besides PSS1, numerous bony vertebrate species have been shown to express a second somatostatin precursor named SS2, also termed SSIII in non-mammalian species, and cortistatin (CST) in most mammals. Peptides derived from this second precursor exhibit a more variable structure than SS1 but all share a unique Pro residue at position 2 (Spier and de Lecea, 2000; Tostivint et al., 2004a) (Fig. 2; Table 2). In placental mammals, CST also possesses an additional Lys residue at its C-terminal extremity. Like SS1, CST and SS2 are flanked at their N-terminus by a dibasic cleavage site. Additional dibasic residues are present in the N-flanking region of the CST precursor (PCST) in some mammalian species including rat and human, suggesting that, in these species, N-terminally-extended forms of CST may also be produced. Consistent with this view, it has been shown that PCST is efficiently processed to both CST-14 and CST-29 in AtT-20 cells (Puebla et al., 1999). In contrast to the SS1 gene, the CST and SS2 genes are specifically expressed in the brain but not in the pancreas or gut (Fabre et al., 2004; Tostivint et al., 2004a). In the central nervous system, the distribution of CST or SS2 mRNA-containing cells is quite variable among the different taxa. Thus, in mammals, CST mRNA is almost exclusively present in the telencephalon, while in non-mammalian species, SS2 mRNA occurs in all subdivisions of the brain and in the spinal cord (Fabre et al., 2004; Tostivint et al., 2004a). As expected from their structural similarities, CST and SS2 can mimic several of the effects of SS1 (de Lecea et al., 1996; Jeandel et al., 1998). However, in rat, CST and SS1 have been found to induce differential responses, in particular on cortical electrical activity, locomotor behavior and paradoxical sleep (Fabre et al., 2004). Interestingly, structure-activity relationship studies have shown that the Pro moiety at position two and the C-terminal Lys residue are crucial for these distinctive effects (Criado et al., 1999). CST binds to all SST subtypes in vitro (Siehler et al., 1998) and interacts with the same binding sites as SS1 in the rodent brain (Spier et al., 2005). It has also been reported that the orphan receptor MrgX2 can selectively bind CST (Robas et al., 2003); however, whether CST is actually the natural ligand of this receptor is currently a matter of debate, since recent data indicate that MrgX2 
is also able to bind with high affinity proadrenomedullin N-terminal peptides (PAMNT; Kamohara et al., 2005). Indeed, the active cores of CST and PAMNT exhibit some structural similarities i.e. they both contain two aromatic amino acids and a $\mathrm{C}$-terminal basic residue that are all arranged in a similar manner (Nothacker et al., 2005).

\subsection{Teleost somatostatin variants}

Among vertebrates, teleost fish represent the group exhibiting the highest number of somatostatin variants. Thus, the occurrence of a third somatostatin precursors (PSSII) has been initially established in anglerfish (Hobart et al., 1980) and later on in other species of fish including trout (Moore et al., 1995, 1999) and goldfish (Lin et al., 1999b). Most peptides derived from PSSII, which are generally 25- to 28-amino acids in length, encompass a $\left[\mathrm{Tyr}^{7}, \mathrm{Gly}^{10}{ }^{10} \mathrm{SS}-14\right.$ sequence at their C-terminal extremity, although other amino acid substitutions have also been reported (Fig. 3; Table 3; Lin et al., 2000a). In some species such as catfish (Magazin et al., 1982; Andrews et al., 1984) and zebrafish (Devos et al., 2002), the third somatostatin variant which has been unsuitably also named SSII (see below) exhibits a very atypical structure (Fig. 4; Table 4). The SSII gene is expressed both in the central nervous system and in peripheral organs, especially in the gastrointestinal tract (Lin et al., 1999b; Moore et al., 1999). In the brain, SSII mRNA occurs almost exclusively in discrete hypothalamic nuclei (Canosa et al., 2004). The functional significance of SSII gene-derived peptides is still poorly understood. However, in some species, SSII and SS1 appear to exhibit distinct actions. For instance, in goldfish, it has been reported that SSII is a more potent inhibitor of basal GH release than SS1 or SS2 (Yunker et al., 2003). Likewise, in trout, SSII, but not SS1, reduces plasma insulin level (Eilerston and Sheridan, 1993). It is also interesting to note that, in trout, the two distinct isoforms of $\mathrm{SST}_{1}$, i.e. $\mathrm{SST}_{1 \mathrm{~A}}$ and $\mathrm{SST}_{1 \mathrm{~B}}$, exhibit higher affinity for PSS1- than for PSSII-derived peptides (Gong et al., 2004). 


\subsection{Other somatostatin variants}

Two somatostatin variants have been characterized in the lampreys. One of them is SS1, and the other one is a 33- to 37-residue peptide which contains a [Ser $\left.{ }^{12}\right] \mathrm{SS}-14$ sequence at its C-terminal extremity (Fig. 5; Table 5; Andrews et al., 1988; Conlon et al., 1995a,b). In both Lampetra fluviatilis and Petromyzon marinus, SS1 predominates in the brain while the $\left[\mathrm{Ser}^{12}\right]$ SS-14-containing variants are primarily found in the pancreas (Andrews et al., 1988;

Sower et al., 1994; Conlon et al., 1995a). In Geotria australis, processing of the [Ser ${ }^{12}$ SSS-14 precursor is tissue-specific: in the pancreas, $\left[\mathrm{Ser}^{12}\right] \mathrm{SS}-14$ is the major molecular form while, in the intestine, the $\left[\mathrm{Ser}^{12}\right] \mathrm{SS}-14$ precursor is processed almost exclusively to the 33 -amino acid form (Conlon et al., 1995b; Wang et al., 1999a). Finally, a molecular variant of somatostatin containing the substitution $\mathrm{Asn}^{5} \rightarrow$ Ser has been isolated from pancreas extracts of a holocephalan fish, the Pacific ratfish (Fig. 5; Table 5; Conlon, 1990). It is currently not known whether this species possesses other somatostatin-related peptides, particularly in the brain. Thus, the view that this $\left[\mathrm{Ser}^{5}\right] \mathrm{SS}-14$ is a product of the SS1 gene cannot totally be ruled out.

\section{Origin of the genes encoding somatostatin-related peptides}

\subsection{Somatostatin 1 gene}

The occurrence of SS1 in all vertebrate classes indicates that the SS1 gene is a very ancient gene, that was likely already present more than $500 \mathrm{Myr}$ ago in the ancestor of all extant vertebrates (Tostivint et al., 2004a). Although somatostatin-like immunoreactive material has been detected in numerous invertebrate species, and even in some plants and bacteria, so far, somatostatin-related peptides have been characterized only in vertebrates. It should be noticed, however, that several invertebrate species, such as Ciona and Drosophila possess somatostatin-like receptors. In Ciona, it has been established that two of these sequences (accession numbers: NP_001042 and NP_001044) are closely related to $\mathrm{SST}_{3}$ and $\mathrm{SST}_{5}$, respectively (Sekiguchi et al., 2007). In the same species, Deyts et al. (2006) have reported no less than 12 somatostatin-like receptor sequences. However, the natural ligands 
for these receptors remain elusive. In Drosophila, two somatostatin-like receptors, referred to as Drostar-1 and -2, have been characterized (Popovici et al., 2001; Kreienkamp et al., 2002). A reverse pharmacological approach has shown that Drostar receptors bind to peptides of the allatostatin C family (Kreienkamp et al., 2002). Although allatostatin C peptides and somatostatin do not exhibit any appreciable sequence similarity (Fig. 6), it is interesting to note that peptides of these two families both possess a disulfide bound and derive from precursors exhibiting the same general organization, with the mature peptide located at the C-terminus (Kreienkamp et al., 2002). Moreover, allatostatin C peptides, as hypothalamic somatostatin, are produced by neurosecretory neurones and are involved in the control of growth (Bendena et al., 1999). Whether these two families of neuropeptides are evolutionarily related or whether their structural similarities are due to convergent evolution remains to be determined.

\subsection{Somatostatin 2 / cortistatin gene}

The SS2 and CST peptides share several important features: they both possess a Pro residue at position 2 and, in contrast to SS1, they are almost exclusively expressed in the brain but not in peripheral organs (Tostivint et al., 2004a). However, because their precursors exhibit very limited sequence similarity, apart from their C-terminus, the phylogenetic relationships between SS2 and CST have remained uncertain for a long time. This issue has been recently resolved when several homologous genes have been shown to occur in the vicinity of both the zebrafish SS2 and human CST genes (Fig. 7; Tostivint et al., 2004b), indicating that SS2 and CST actually derive from orthologous genes. In the opossum, the only marsupial species whose genome has been sequenced up to now, in silico analysis has revealed that the SS2 peptide does not possess a Lys moiety at its C-terminus (Fig. 1), suggesting that the acquisition of this residue is a recent event that happened late during evolution of the placental mammalian lineage.

In human, it has been shown that the SS2/CST gene maps to $1 \mathrm{p} 36$ close to several other genes that have relatives in the vicinity of the SS1 gene on 3q28. This observation strongly 
suggests that $1 \mathrm{p} 36$ and $3 \mathrm{q} 28$ are two paralogous regions and thus arose by segmental duplication, potentially as part of a whole genome duplication event (Fig. 8; Tostivint et al., 2006). This duplication event may coincide with one of the two rounds of tetraploidization that, according to the $2 \mathrm{R}$ hypothesis, are thought to have occurred very early during vertebrate evolution, i.e. before the origin of gnathostomes (Dehal and Boore, 2005). To test this hypothesis, it would be interesting to look for the existence of an SS2 gene in elasmobranchs, and even in lampreys. Whether the lamprey [Ser $\left.{ }^{12}\right]$ SS-14 variant represents an SS2 gene product or results from gene duplication within the cyclostome lineage is currently unknown (Tostivint et al., 2004b).

\subsection{Teleost-specific somatostatin genes}

As mentioned above, most peptides derived from PSSII contain the $\left[\mathrm{Tyr}^{7}, \mathrm{Gly}^{10}\right] \mathrm{SS}-14$ sequence at their C-terminal extremity. In Fugu, as in Tetraodon, the SSII gene is in close proximity to the SS1 gene, suggesting that the two genes arose by a local duplication (Tostivint et al., 2004b). This local duplication likely occurred relatively early during teleost evolution since the SSII gene is also present in eel (Conlon et al., 1988a) which is viewed as a very basal euteleost species. It should be noted that this duplication event is totally distinct from the fish-specific genome duplication event also called 3R (see below).

In contrast to most other teleost SSII, catfish and zebrafish SSII exhibit a very unusual structure (Magazin et al., 1982; Andrews et al., 1984; Devos et al., 2002). The evolutionary relationship between the common SSII and this peculiar isoform has long remained unclear. The fact that, in zebrafish, atypical SSII and SS1 genes are localized on two distinct chromosomes strongly suggested that the SSII gene and the atypical SSII gene had distinct evolutionary histories and were thus paralogous genes (Tostivint et al., 2004a). We show here for the first time that the zebrafish genome contains a gene encoding for a $\left[\right.$ Tyr $^{7}$, Gly $\left.^{10}\right]$ SS14 variant (Fig. 3), in addition to the atypical SSII gene (Fig. 4). The fact that this gene maps very closely to the SS1 gene (Fig. 9), like in pufferfish, indicates that it is orthologous to the common SSII gene. The occurrence in a same species of both the 
common SSII gene and the atypical SSII gene provides strong evidence that these two genes are paralogous. The atypical SSII gene may result from the $3 \mathrm{R}$ event that occurred relatively early in the ray-finned fish lineage. Alternatively, it may have appeared much later during teleost evolution. The fact that all the species possessing this gene - namely catfish, zebrafish and the fruit-eating fish, pacu (Ferraz de Lima et al., 1999) - belong to the group of ostariophysi would support the latter hypothesis.

In some species, such as the trout and goldfish (Uesaka et al., 1995; Lin et al., 1999b; Moore et al., 1999; Fig. 3), the occurrence of two copies of the typical SSII gene has been demonstrated. In the fugu, we have also detected two copies of the SS1 gene, that we propose to name SS1a and SS1b (Fig. 1). It is likely that all these copies result from the tetraploidization event that has occurred in the ray-finned fish lineage (Amores et al., 1998; Hoegg et al., 2004). Alternatively, in particular in trout, the two SSII gene copies may result from the additional tetraploidization event that has affected the salmonid fish genome about 25 Myr ago (Allendorf et al., 1983; Moghadam et al., 2005).

\subsection{Other somatostatin genes}

The occurrence of somatostatin-like immunoreactivity, that does not derive from the CST gene, has been reported in the proximal midgut of somatostatin-deficient mice, strongly suggesting the existence of a novel somatostatin-related gene in mammals (Ramirez et al., 2002). In support of this hypothesis, a novel peptide, termed thrittene, whose sequence corresponds to S-28 $8_{(1-13)}$ but does not derive from PSS1 or PCST, has also been characterized in the rat and monkey intestinal tract (Ensinck et al., 2002). Further studies will be necessary to identify the mysterious gene encoding this novel somatostatin-related peptide.

\section{Evolutionary relationships between somatostatin- and urotensin II-related}

Urotensin II (UII) has been first isolated from the caudal neurosecretory system of teleost fish on the basis of its smooth muscle contracting activity (Pearson et al., 1980). It has been 
subsequently shown that UII exists in all vertebrate classes from agnathans to mammals, including human (Conlon et al., 1992; 1997a; Coulouarn et al., 1998, 1999). The primary structure of UII has been relatively well conserved during vertebrate evolution, notably in its C-terminal region (Conlon et al., 1997a; Coulouarn et al., 1998, 1999). The occurrence of a second UII isoform, named UII-related peptide (URP), has recently been reported in tetrapods and teleosts (Sugo et al., 2003; Tostivint et al., 2006). A single receptor for UII and URP, called UT, has been identified so far (Ames et al., 1999; Mori et al., 1999; Nothacker et al., 1999; Liu et al., 1999). Pharmacological studies have shown that UII and/or URP may be implicated in the control of a broad range of biological processes including cardiovascular activities, homeostasis, metabolic functions and behaviors (Douglas et al., 2004; Lihrmann et al., 2006; Do Rego et al., 2008). However, to date, the physiological roles of UII and URP have not been clearly identified.

It has been initially recognized that UII and SS1 exhibit limited structural similarities including a disulfide bridge and a common motif, Phe-Trp-Lys, which is essential for their biological activity (Fig. 10; Veber et al., 1979; Flohr et al., 2002; Labarrère et al., 2003; Chatenet et al., 2004), so that UII has been first described as a somatostatin-like peptide (Pearson et al., 1980). In addition, it has been found that the organization of the precursors of UII, SS1 and related peptides are globally similar (Shen et al., 1982; Ohsako et al., 1986; Tostivint et al., 1996; Coulouarn et al., 1998, 1999). Nevertheless, characterization of the cDNA encoding the UII precursor has shown that prepro-UII and prepro-SS1 do not exhibit appreciable sequence identity (Ohsako et al., 1986; Coulouarn et al., 1998, 1999) and hence, it was concluded that the UII and SS1 precursors were probably not derived from a common ancestral gene.

It has been recently shown however that, in several species, including human, rodent, chicken and zebrafish, the UII gene is closely linked to the SS2/CST gene, while the gene encoding the novel UII-related peptide, URP, is located in the same chromosomal region as the SS1 gene. From these data, it has been proposed that the genes encoding UII- and somatostatin-related peptides may have arisen from a common ancestral gene which 
underwent two rounds of gene duplication (Tostivint et al., 2006). The local duplication must have occurred early during vertebrate evolution since both somatostatin and UII peptides are present in lampreys, while the segment/chromosome duplication may correspond to one of the whole genome duplications that have affected early vertebrates (Tostivint et al., 2006). The existence of both CST/SS2 and URP genes in fish (Tostivint et al., 2004b; 2006) supports this scenario.

As far as the receptors are concerned, SSTs and UT display relatively high sequence similarity (Marchese et al., 1995; Tal et al., 1995). A common evolutionary origin for SSTs and UT is also strongly supported by the chromosomal localization of their genes. Indeed, the $\mathrm{SST}_{3}$ and UT genes are physically linked at the same locus, suggesting that the genes encoding the two receptors arose by local duplication (Tostivint et al., 2006).

Taken together, these observations provide strong evidence for a co-evolutionary process of the somatostatin/UII family of peptides and their cognate receptors SSTs/UT, consistent with the notion that related G protein-coupled receptors, such as NPY receptors (CerdaReverter and Larhammar, 2000), VIP/PACAP receptors (Sherwood et al., 2000; Vaudry et al., 2000) and opiate receptors (Dores et al., 2002), are also usually activated by paralogous peptides.

\section{Proposal for a novel nomenclature of somatostatin gene family}

As mentionned above, only two somatostatin variants are known in mammals, namely SS1 and SS2. Because we are well aware that the designations somatostatin and cortistatin are widely accepted by all researchers working on mammalian somatostatin-related peptides, we think that it would not be judicious to change this nomenclature. We thus propose to maintain the terms somatostatin and cortistatin to designate mammalian SS1 and SS2, respectively. However, the current nomenclature used to designate somatostatinrelated peptides in other vertebrate classes, particularly in fish, is really confusing. In particular, distinct peptides, such as the common and atypical SSII isoforms of teleosts, that derive from paralogous genes, have received the same designation ( $\mathrm{Su}$ et al., 1988; Lin et 
al., 1999). Reciprocally, some peptides, that are clearly encoded by orthologous genes, are named differently. This is the case for SS2, which in teleosts is also designated as somatostatin III (Lin et al., 1999; Nelson and Sheridan, 2005) or somatostatin 3 (Devos et al., 2002). We therefore suggest to reconsider this nomenclature, which was primarily based on the chronology of the characterization of all these variants, at the light of the evolutionary relationship between somatostatin peptides. Taking into account these considerations, we propose to apply the following rules: $i$ ) all peptides that derive from orthologous genes should receive, as far as possible, the same name; ii) each somatostatinrelated peptide should be named SS followed by an arabian number; and iii) the numerical order of these numbers should reflect the phylogenetic history of the genes. Hence, we suggest to apply the following nomenclature, at least for comparative studies, involving non-mammalian species:

- SS1 should designate the common isoform (somatostatin-14), that occurs in all vertebrates.

- SS2 should designate variants containing a Pro residue at position 2, that occur in osteichthyans.

- SS3 should designate variants containing both $\mathrm{Tyr}^{7}$ and Gly ${ }^{10}$ residues, that occur in teleost fish.

- SS4 should designate variants containing Tyr, Ser, Arg and Ala residues at positions 6, 10, 11 and 13, respectively, that only occur in species of the group of ostariophysi.

- For all these peptides, as well as for UII-related peptides, the greek letters $\alpha$ and $\beta$ should be used to designate variants occurring in some teleost species that likely arose from the fishspecific tetraploidization event 3R.

\section{Concluding remarks}

The data presented here support the existence of at least four distinct somatostatin genes in vertebrates as illustrated in figure 11: $i$ ) the somatostatin 1 (SS1) gene which clearly represents the ancestral gene of the family, ii) the somatostatin 2/cortistatin (SS2/CST) gene which occurs in all osteichthyans and arose from the SS1 gene by segment/chromosome 
duplication, iii) the somatostatin 3 (SS3) gene, previously termed SSII gene, which exists only in teleosts and results from a local duplication of the SS1 gene, and $i v$ ) the somatostatin 4 (SS4) gene, previously termed atypical SSII gene, which is restricted to the group of ostariophysi and whose origin is currently unknown. In teleost species, some of these genes can be found in two copies that may result from the fish-specific genome duplication (Fig. 11). The data also suggest that somatostatin- and urotensin II-related peptides most likely derive from a same ancestral gene, as the result of a local duplication that arose very early during vertebrate evolution. Finally, they show that SS2 and URP genes arose simultaneously by a segment/chromosome duplication that can be interpreted within the $2 \mathrm{R}$ framework (Fig. 11).

Gene duplication is thought to have played an important role in the appearance of novel gene functions, since newly created genes are under relaxed selected pressure and are thus free to diverge and evolve novel functions or subfunctionalize and acquire distinct expression patterns (Lynch and Force, 2000; Lynch, 2002; Cusack and Wolfe, 2007). The physiological roles of SS1 have been thoroughly investigated and it has been shown that the actions of SS1 on various organs are associated with a wide range of regulations on growth, development, metabolic and immune responses (Olias et al., 2004). Other somatostatin isoforms, such as CST in mammals (Fabre et al., 2004) and, to a lesser extend, SSII in teleost fish (Nelson and Sheridan, 2005) have been shown to exert some markedly different effects as compared to SS1, consistent with their distinct tissue distribution. However, their physiological significance is currently largely unknown. Further studies will be necessary to better understand the functional implications of the structural diversity of somatostatinrelated peptides.

\section{Acknowledgments}

We wish to express our gratitude to the researchers who have contributed to this project, especially Howard A. Bern, J. Michael Conlon, Robert M. Dores, Marc Ekker, Michele Trabucchi and Mauro Vallarino. This work was supported by INSERM (U413), the 
European Institute for Peptide Research (IFRMP 23) and the Conseil Régional de HauteNormandie. 


\section{References}

Allendorf, F.W., Thorgaard, G.H., 1984. Tetraploidy and the evolution of salmonid fish. In:

Turner, J.B. (Ed.), Evolutionary Genetics of Fish. Plenum Press, New York, pp 1-53. Ames, R.S., Sarau, H.M., Chambers, J.K, Willette, R.N., Aiyar, N.V., Romanic, A.M., Louden, C.S., Foley, J.J., Sauermelch, C.F., Coatney, R.W., Ao, Z., Disa, J., Holmes, S.D., Stadel, J.M., Martin, J.D., Liu, W.S., Glover, G.I., Wilson, S., McNulty, D.E., Ellis, C.E., Elshourbagy, N.A., Shabon, U., Trill, J.J., Hay, D.W., Douglas, S.A., 1999. Human urotensin-II is a potent vasoconstrictor and agonist for the orphan receptor GPR14. Nature 401, 282-286.

Amores, A., Force, A., Yan, Y.L., Joly, L., Amemiya, C., Fritz, A., Ho, R.K., Langeland, J., Prince, V., Wang, Y.L., Westerfield, M., Ekker, M., Postlethwait, J.H., 1998.

Zebrafish hox clusters and vertebrate genome evolution. Science 282, 1711-1714.

Andoh, T., Nagasawa, H., 1998. Purification and structural determination of insulins, glucagons and somatostatin from stone flounder, Kareius bicoloratus. Zool. Sci. 15, 939943.

Andrews, P.C., Pubols, M.H., Hermodson, M.A., Shears, B.T., Dixon, J.E., 1984. Structure of the 22-residue somatostatin from catfish. An O-glycosylated peptide having multiple forms. J. Biol. Chem. 259, 13267-13272.

Andrews, P.C., Pollock, H.G., Elliott, W.M., Youson, J.H., Plisetskaya, E.M., 1988. Isolation and characterization of a variant somatostatin-14 and two related somatostatins of 34 and 37 residues from lamprey (Petromyzon marinus). J. Biol. Chem. 268, 15809-15814.

Argenton, F., Zecchin, E., Bortolussi, M., 1999. Early appearance of pancreatic hormoneexpressing cells in the zebrafish embryo. Mech. Dev. 87, 217-221.

Bendena, W.G., Donly, B.C., Tobe, S.S., 1999. Allatostatins: a growing family of neuropeptides with structural and functional diversity. Ann. N. Y. Acad. Sci. 897, 311329.

Bohlen, P., Brazeau, P., Esch, F., Ling, N., Guillemin, R., 1980. Isolation and chemical 
characterization of somatostatin-28 from rat hypothalamus. Regul. Pept. 2, 359-369. Brazeau, P., Vale, W., Burgus, R., Ling, N., Butcher, M., Rivier, J., Guillemin, R., 1973. Hypothalamic polypeptide that inhibits the secretion of immunoreactive pituitary growth hormone. Science 179, 77-79.

Bruneau, G., Tillet, Y., 1998. Localization of the preprosomatostatin-mRNA by in situ hybridization in the ewe hypothalamus. Peptides 19, 1749-1758.

Calbet, M., Guadano-Ferraz, A., Spier, A.D., Maj, M., Sutcliffe, J.G., Przewlocki, R., de Lecea, L., 1999. Cortistatin and somatostatin mRNAs are differentially regulated in response to kainate. Mol. Brain. Res. 72, 55-64.

Canosa, L.F., Cerda-Reverter, J.M., Peter, R.E., 2004. Brain mapping of three somatostatin encoding genes in the goldfish. J. Comp. Neurol. 474, 43-57.

Cavanaugh, E.S., Nielsen, P.F., Conlon, J.M., 1996. Isolation and structural characterization of proglucagon-derived peptides, pancreatic polypeptide, and somatostatin from the urodele Amphiuma tridactylum. Gen. Comp. Endocrinol. 101, 12-20.

Cerda-Reverter, J.M., Larhammar, D., 2000. Neuropeptide Y family of peptides: structure, anatomical expression, function, and molecular evolution. Biochem. Cell. Biol. 8, 371392.

Chatenet, D., Dubessy, C., Leprince, J., Boularan, C., Carlier, L., Segalas-Milazzo, I., Guilhaudis, L., Oulyadi, H., Davoust, D., Scalbert, E., Pfeiffer, B., Renard, P., Tonon, M.C., Lihrmann, I., Pacaud, P., Vaudry, H., 2004. Structure-activity relationships and structural conformation of a novel urotensin II-related peptide. Peptides 25, 18191830.

Conlon, J.M., 1984. Isolation and structure of guinea pig gastric and pancreatic somatostatin. Life Sci. 35, 213-220.

Conlon, J.M., 1990. [Ser $\left.{ }^{5}\right]$ somatostatin-14: isolation from the pancreas of a holocephalan fish, the Pacific ratfish, Hydrolagus colliei. Gen. Comp. Endocrinol. 180, 314-320.

Conlon, J.M., Mc Carthy, D.M., 1984. Fragments of prosomatostatin from a human pancreatic tumour. Mol. Cell. Endocrinol. 38, 81-86. 
Conlon, J.M., Larhammar, D., 2005. The evolution of neuroendocrine peptides. Gen. Comp. Endocrinol. 142, 53-59.

Conlon, J.M., Agoston, D.V., Thim, L., 1985. An elasmobranchian somatostatin: primary structure and tissue distribution in Torpedo marmorata. Gen. Comp. Endocrinol. 60, 406413.

Conlon, J.M., Davis, M.S., Falkmer, S., Thim, L., 1987. Structural characterization of peptides derived from prosomatostatins I and II isolated from the pancreatic islets of two species of teleostean fish: the daddy sculpin and the flounder. Eur. J. Biochem. 168, 647-652.

Conlon, J.M., Deacon, C.F., Hazon, N., Henderson, I.W., Thim, L., 1988a. Somatostatinrelated and glucagon-related peptides with unusual structural features from the European eel (Anguilla anguilla). Gen. Comp. Endocrinol. 72, 181-189.

Conlon, J.M., Askensten, U., Falkmer, S., Thim, L., 1988b. Primary structures of somatostatins from the islet organ of the hagfish suggest an anomalous pathway of posttranslational processing of prosomatostatin-1. Endocrinology 122, 1855-1859.

Conlon, J.M., Hicks, J.W., 1990. Isolation and structural characterization of insulin, glucagon and somatostatin from the turtle, Pseudemys scripta. Peptides 11, 461-466.

Conlon, J.M., O'Harte, F., Smith, D.D., Tonon, M.C., Vaudry, H., 1992. Isolation and primary structure of urotensin II from the brain of a tetrapod, the frog Rana ridibunda. Biochem. Biophys. Res. Commun. 188, 578-583.

Conlon, J.M., Bondereva, V., Rusakov, Y., Plisetskaya, E.M., Mynarcik, D.C., Whittaker, J., 1995a. Characterization of insulin, glucagon and somatostatin from the river lamprey, Lampetra fluviatilis. Gen. Comp. Endocrinol. 100, 96-105.

Conlon, J.M., Nielsen, P.F., Youson, J.H., Potter, I.C., 1995b. Proinsulin and somatostatin from the islet organ of the southern-hemisphere lamprey Geotria australis. Gen. Comp. Endocrinol. 100, 413-422.

Conlon, J.M., Tostivint, H., Vaudry, H., 1997a. Somatostatin- and urotensin II-related peptides: molecular diversity and evolutionary perspectives. Regul. Pept. 69, 95-103. 
Conlon, J.M., Secor, S.M., Adrian, T.E., Mynarcik, D.C., Whittaker, J., 1997b. Purification and characterization of islet hormones (insulin, glucagon, pancreatic, polypeptide and somatostatin) from the Burmese python, Python molurus. Regul. Pept. 71, 191-198.

Coulouarn, Y., Lihrmann, I., Jégou, S., Anouar, Y., Tostivint, H., Beauvillain, J.C., Conlon, J.M., Bern, H.A., Vaudry, H., 1998. Cloning of the cDNA encoding the urotensin II precursor in frog and human reveals intense expression of the urotensin II gene in motoneurons of the spinal cord. Proc. Natl. Acad. Sci. USA 95, 15803-15808.

Coulouarn, Y., Jegou, S., Tostivint, H., Vaudry, H., Lihrmann, I., 1999. Cloning, sequence analysis and tissue distribution of the mouse and rat urotensin II precursors. FEBS Lett. 457, 28-32.

Criado, J.R., Li, H., Jiang, X., Spina, M., Huitron-Resendiz, S., Liapakis, G., Calbet, M., Siehler, S., Henriksen, S.J., Koob, G., Hoyer, D., Sutcliffe, J.G., Goodman, M., de Lecea, L., 1999. Structural and compositional determinants of cortisatin activity. J. Neurosci. Res. 56, 611-619.

Cusack, B.P., Wolfe, K.H., 2007. When gene marriages don't work out: divorce by subfunctionalization. Trends Genet. 23, 270-272.

de Lecea, L., Criado, J.R., Prospero-Garcia, O., Gautvik, K.M., Schweitzer, P., Danielson, P.E., Dunlop, C.L., Siggins, G.R., Henriksen, S.J., Sutcliffe, J.G., 1996. A cortical neuropeptide with neuronal depressant and sleep-modulating properties. Nature 381, 242-245.

de Lecea, L., Ruiz-Lozano, P., Danielson, P.E., Peelle-Kirley, J., Foye, P.E., Frankel, W.N., Sutcliffe, J.G., 1997. Cloning, mRNA expression, and chromosomal mapping of mouse and human preprocortistatin. Genomics 42, 499-506.

Dehal, P., Boore, J.L., 2005. Two rounds of whole genome duplication in the ancestral vertebrate. PLoS Biol. 3, e314.

Devos, N., Deflorian, G., Biemar, F., Bortolussi, M., Martial, J.A., Peers, B., Argenton, F., 2002. Differential expression of two somatostatin genes during zebrafish embryonic development. Mech. Dev. 115, 133-137. 
Deyts, C., Casane, D., Vernier, P., Bourrat, F., Joly, J.S., 2006. Morphological and gene expression similarities suggest that the ascidian neural gland may be osmoregulatory and homologous to vertebrate peri-ventricular organs. Eur. J. Neurosci. 24, 2299-2308.

Do Rego, J.C., Leprince, J., Scalbert, E., Vaudry, H., Costentin, J., 2008. Behavioral actions of urotensin-II. Peptides (in press).

Dores, R.M., Lecaude, S., Bauer, D., Danielson, P.B., 2002. Analyzing the evolution of the opioid/orphanin gene family. Mass Spectrom. Rev. 21, 220-243.

Douglas, S.A., Dhanak, D., Johns, D.G., 2004. From « gills to pills »: urotensin-II as a regulator of mammalian cardiorenal function. Trends Pharmacol. Sci. 25, 76-85.

Durand, D., Hoberman, R., 2006. Diagnosing duplications - can it be done? Trends Genet. 22, 156-164.

Eilertson, C.D., Sheridan, M.A., 1993. Differential effects of somatostatin-14 and somatostatin-25 on carbohydrate and lipid metabolism in rainbow trout Oncorhynchus mykiss. Gen. Comp. Endocrinol. 92, 62-70.

Ensinck, J.W., Baskin, D.G., Vahl, T.P., Vogel, R.E., Laschansky, E.C., Francis, B.H., Hoffman, R.C., Krakover, J.D., Stamm, M.R., Low, M.J., Rubinstein, M., Otero-Corchon, V., D'Alessio, D.A., 2002. Thrittene, homologous with somatostatin-28 $(1-13)$, is a novel peptide in mammalian gut and circulation. Endocrinology 143, 2599-2609.

Esch, F., Bohlen, P., Ling, N., Benoit, R., Brazeau, P., Guillemin, R., 1980. Primary structure of ovine hypothalamic somatostatin-28 and somatostatin-25. Proc. Natl. Acad. Sci. USA 77, 6827-6831.

Fabre, V., Spier, A.V., Winsky-Sommerer R., Criado, J.R., de Lecea, L., 2004. CortistatinA novel member of the somatostatin gene family. In: Srikant, C.B. (Ed.), Somatostatin. Kluwer, Academic Publishers, pp 29-45.

Ferraz de Lima, J.A., Oliveira, B., Conlon, J.M., 1999. Purification and characterization of insulin and peptides derived from proglucagon and prosomatostatin from the fruit- 
eating fish, the pacu Piaractus mesopotamicus. Comp. Biochem. Physiol. 122, 127135 .

Flohr, S., Kurz, M., Kostenis, E., Brkovich, A., Fournier, A., Klabunde, T., 2002. Identification of nonpeptidic urotensin II receptor antagonists by virtual screening based on a pharmacophore model derived from structure-activity relationships and nuclear magnetic resonance studies on urotensin II. J. Med. Chem. 45, 1799-1805.

Fuhrmann, G., Heilig, R., Kempf, J., Ebel, A., 1990. Nucleotide sequence of the mouse preprosomatostatin gene. Nucleic Acids Res. 18, 1287.

Fukusumi, S., Kitada, C., Takekawa, S., Kizawa, H., Sakamoto, J., Miyamoto, M., Hinuma, S., Kitano, K., Fujino, M., 1997. Identification and characterization of a novel human cortistatin-like peptide. Biochem. Biophys. Res. Commun. 232, 157-163.

Funckes, C.L., Minth, C.D., Deschenes, R., Magazin, M., Tavianini, M.A., Sheets, M., Collier, K., Weith, H.L., Aron, D.C., Roos, B.A., Dixon, J.E., 1983. Cloning and characterization of a mRNA-encoding rat preprosomatostatin. J. Biol. Chem. 238, 8781-8787.

Furu, L.M., Kazmer, G.W., Strausbaugh, L., Zinn, S.A., 1999. Cloning and characterization of the bovine somatostatin gene. J. Anim. Sci. 77, 492-493.

Gong, J.Y., Kittilson, J.D., Slagter, B.J., Sheridan, M.A., 2004. The two subtype 1 somatostatin receptors of rainbow trout, Tsst $1 \mathrm{~A}$ and Tsst1B, possess both distinct and overlapping ligand binding and agonist-induced regulation features. Comp. Biochem. Physiol. B 138, 295-303.

Goodman, R.H., Jacobs, J.W., Dee, P.C., Habener, J.F., 1982. Somatostatin-28 encoded in a cloned cDNA obtained from a rat medullary thyroid carcinoma. J. Biol. Chem. 257, 1156-1159.

Hobart, P., Crawford, R., Shen, L.P., Pictet, R., Rutter, W.J., 1980. Cloning and sequence analysis of cDNAs encoding two distinct somatostatin precursors found in the endocrine pancreas of anglerfish. Nature 288, 137-141. 
Hoegg, S., Brinkmann, H., Taylor, J.S., Meyer, A., 2004. Phylogenetic timing of the fishspecific genome duplication correlates with the diversification of teleost fish. J. Mol. Evol. 59, 190-203.

Jaillon, O., Aury, J.M., Brunet, F., Petit, J.L., Stange-Thomann, N., Mauceli, E., Bouneau, L., Fischer, C., Ozouf-Costaz, C., Bernot, A., Nicaud, S., Jaffe, D., Fisher, S., Lutfalla, G., Dossat, C., Segurens, B., Dasilva, C., Salanoubat, M., Levy, M., Boudet, N., Castellano, S., Anthouard, V., Jubin, C., Castelli, V., Katinka, M., Vacherie, B., Biemont, C., Skalli, Z., Cattolico, L., Poulain, J., De Berardinis, V., Cruaud, C., Duprat, S., Brottier, P., Coutanceau, J.P., Gouzy, J., Parra, G., Lardier, G., Chapple, C., McKernan, K.J., McEwan, P., Bosak, S., Kellis, M., Volff, J.N., Guigo, R., Zody, M.C., Mesirov, J., Lindblad-Toh, K., Birren, B., Nusbaum, C., Kahn, D., RobinsonRechavi, M., Laudet, V., Schachter, V., Quetier, F., Saurin, W., Scarpelli, C., Wincker, P., Lander, E.S., Weissenbach, J., Roest-Crollius, H., 2004. Genome duplication in the teleost fish Tetraodon nigroviridis reveals the early vertebrate proto-karyotype. Nature 431, 946-957.

Jeandel, L., Okuno, A., Kobayashi, T., Kikuyama, S., Tostivint, H., Lihrmann, I., Chartrel, N., Conlon, J.M., Fournier, A., Tonon, M.C., Vaudry, H., 1998. Effects of the two somatostatin variants somatostatin-14 and $\left[\mathrm{Pro}^{2}, \mathrm{Met}^{13}\right]$ somatostatin-14 on receptor binding, adenylyl cyclase activity and growth hormone release from the frog pituitary. J. Neuroendocrinol. 10, 187-192.

Kamohara, M., Matsuo, A., Takasaki, J., Kohda, M., Matsumoto, M., Matsumoto, S., Soga, T., Hiyama, H., Kobori, M., Katou, M., 2005. Identification of MrgX2 as a human Gprotein-coupled receptor for proadrenomedullin N-terminal peptides. Biochem.

Biophys. Res. Commun. 330, 1146-1152.

Kim, J.B., Gadsboll, V., Whittaker, J., Barton, B.A., Conlon, J.M., 2000.

Gastroenteropancreatic hormones (insulin, glucagon, somatostatin, and multiple forms of PYY) from the pallid sturgeon, Scaphirhynchus albus (Acipenseriformes). Gen.

Comp. Endocrinol. 120, 353-363. 
Kittilson, J.D., Moore, C.A., Sheridan, M.A., 1999. Polygenic expression of somatostatin in rainbow trout, Oncorhynchus mykiss: evidence of a preprosomatostatin encoding somatostatin-14. Gen. Comp. Endocrinol. 114, 88-96.

Kreienkamp, H.J., Larusson, H.J., Witte, I., Roeder, T., Birgül, N., Hönck, H.H., Harder, S., Ellinghausen, G., Buck, F., Richter, D., 2002. Functional annotation of two orphan Gcoupled receptors, Drostar1 and -2, from Drosophola melanogaster and their ligands by reverse pharmacology. J. Biol. Chem. 277, 39937-39943.

Labarrere, P., Chatenet, D., Leprince, J., Marionneau, C., Loirand, G., Tonon, M.C., Dubessy, C., Scalbert, E., Pfeiffer, B., Renard, P., Calas, B., Pacaud, P., Vaudry, H., 2003. Structure-activity relationships of human urotensin II and related analogues on rat aortic ring contraction. J. Enzyme Inhib. Med. Chem. 18, 77-88.

Lin, X., Peter, R.E., 2003. Somatostatin-like receptors in goldfish: cloning of four new receptors. Peptides 24, 53-63.

Lin, X., Janovick, J.A., Brothers, S., Conn, P.M., Peter, R.E., 1999a. Molecular cloning and expression of two type one somatostatin receptors in goldfish brain. Endocrinology $140,5211-5219$.

Lin, X., Otto, C.J., Peter, R.E., 1999b. Expression of three distinct somatostatin messenger ribonucleic acids (mRNAs) in goldfish brain: characterization of the complementary deoxyribonucleic acids, distribution and seasonal variation of the mRNAs, and action of a somatostatin-14 variant. Endocrinology 140, 2089-2099.

Lin, X., Otto, C.J., Cardenas, R., Peter, R.E., 2000a. Family of peptides and its receptors in fish. Can. J. Physiol. Pharmacol. 78, 1053-1066.

Lin, X., Janovick, J.A., Cardenas, R., Conn, P.M., Peter, R.E., 2000b. Molecular cloning and expression of a type-two somatostatin receptor in goldfish brain and pituitary. Mol. Cell. Endocrinol. 166, 75-87.

Lin, X., Nunn, C., Hoyer, D., Rivier, J., Peter, R.E., 2002. Identification and characterization of a type five-like somatostatin receptor in goldfish pituitary. Mol. Cell. Endocrinol. 189, 105-116. 
Liu, Q., Pong, S.S., Zeng, Z., Zhang, Q., Howard, A.D., Williams, D.L., Jr., Davidoff, M., Wang, R., Austin, C.P., McDonald, T.P., Bai, C., George, S.R., Evans, J.F., Caskey, C.T., 1999. Identification of urotensin II as the endogenous ligand for the orphan Gprotein-coupled receptor GPR14. Biochem. Biophys. Res. Commun. 266, 174-178.

Lihrmann I., Bern H.A., Vaudry H., 2006. Urotensin II and urotensin II-related peptide. In:

Kastin, A.J., (Ed.), Handbok of Biologically Active Peptides. Elsevier, 109, 815-823. Lynch, M., 2002.Gene duplication and evolution. Science 297, 945-947.

Lynch M., Force A., 2000. The probability of duplicate gene preservation by subfunctionalization. Genetics 154, 459-473.

Magazin, M., Minth, C.D., Funckes, C.L., Deschenes, R., Tavianini, M.A., Dixon, J.E., 1982. Sequence of a cDNA encoding pancreatic preprosomatostatin-22. Proc. Natl. Acad. Sci. USA 79, 5152-5156.

Marchese, A., Heiber, M., Nguyen, T., Heng, H.H., Saldivia, V.R., Cheng, R., Murphy, P. M., Tsui, L.C., Shi, X., Gregor, P., O’Dowd, B.F., Docherty, J.M., 1995. Cloning and chromosomal mapping of three novel genes, GPR9, GPR10, and GPR14, encoding receptors related to interleukin 8 , neuropeptide $\mathrm{Y}$, and somatostatin receptors. Genomics 29, 335-344.

Minth, C.D., Taylor, W.L., Magazin, M., Tavianini, M.A., Collier K., Weith, H.L., Dixon, J.E., 1982. The structure of cloned DNA complementary to catfish pancreatic somatostatin-14 messenger RNA. J. Biol. Chem. 257, 10372-10377.

Moghadam, H.K., Ferguson, M.M., Danzmann, R.G., 2005. Evidence for Hox gene duplication in rainbow trout (Oncorhynchus mykiss): a tetraploid model species. J. Mol. Evol. 61, 804-818.

Møller, L.N., Stidsen, C.E., Hartmann, B., Holst, J.J., 2003. Somatostatin receptors. Biochim. Biophys. Acta 1616, 1-84.

Montminy, M.R., Goodman, R.H., Horovitch, S.J., Habener, J.F., 1984. Primary structure of the gene encoding rat preprosomatostatin. Proc. Natl. Acad. Sci. USA 81, 3337-3340. 
Moore, C.A., Kittilson, J.D., Dahl, S.K., Sheridan, M.A., 1995. Isolation and characterization of a cDNA encoding for preprosomatostatin containing $\left[\mathrm{Tyr}^{7}, \mathrm{Gly}^{10}\right]$-somatostatin-14 from the endocrine pancreas of rainbow trout, Oncorhynchus mykiss. Gen. Comp. Endocrinol. 98, 3-21.

Moore, C.A., Kittilson, J.D., Ehrman, M.M., Sheridan, M.A., 1999. Rainbow trout (Oncorhynchus mykiss) possess two somatostatin mRNAs that are differentially expressed. Am. J. Physiol. 277, R1553-1561.

Mori, M., Sugo, T., Abe, M., Shimomura, Y., Kurihara, M., Kitada, C., Kikuchi, K., Shintani, Y., Kurokawa, T., Onda, H., Nishimura, O., and Fujino, M., 1995. Urotensin II is the endogenous ligand of a G-protein-coupled orphan receptor, SENR (GPR14). Biochem. Biophys. Res. Commun. 265, 123-129.

Nelson, L.E., Sheridan, M.A., 2005. Regulation of somatostatins and their receptors in fish. Gen. Comp. Endocrinol. 142, 117-133

Nguyen, T.M., Wright, J.R., Nielsen, P.F., Conlon, J.M., 1995. Characterization of the pancreatic hormones from the Brockmann body of the tilapia: implications for islet xenograft studies. Comp. Biochem. Physiol. 111C, 33-44.

Nishii, M., Moverus, B., Bukovskaya, O.S., Takahashi, A., Kawauchi, H., 1995. Isolation and characterization of $\left[\mathrm{Pro}^{2}\right]$ somatostatin-14 and melanotropins from Russian sturgeon, Acipenser gueldenstaedti Brandt. Gen. Comp. Endocrinol. 99, 6-12.

Noe, B.D., Spiess, J., Rivier, J.E., Vale, W., 1979. Isolation and characterization of somatostatin from anglerfish pancreatic islet. Endocrinology 105, 1410-1415.

Nothacker, H.P., Wang, Z., McNeill, A.M., Saito, Y., Merten, S., O'Dowd, B., Duckles, S.P., Civelli, O., 1999. Identification of the natural ligand of an orphan G-proteincoupled receptor involved in the regulation of vasoconstriction. Nat. Cell. Biol. 1, 383385.

Nothacker, H.P., Wang, Z., Zeng, H., Mahata, S.K., O'Connor, D.T., Civelli, O., 2005. Proadrenomedullin N-terminal peptide and cortistatin activation of $\mathrm{MrgX} 2$ receptor is based on a common structural motif. Eur. J. Pharmacol. 519, 191-193. 
Ohsako, S., Ishida, I., Ichikawa, T., Deguchi, T., 1986. Cloning and sequence analysis of cDNAs encoding precursors of urotensin II-alpha and -gamma. J. Neurosci. 6, 27302735 .

Olias, G., Viollet, C., Kusserow, H., Epelbaum, J., Meyerhof W., 2004. Regulation and function of somatostatin receptors. J. Neurochem. 89, 1057-1091.

Panetta, R., Greenwood, M.T., Warszynska, A., Demchyshyn, L.L., Day, R., Niznik, H.B., Srikant, C.B., Patel, Y.C., 1994. Molecular cloning, functional characterization, and chromosomal localization of a human somatostatin receptor (somatostatin receptor type 5) with preferential affinity for somatostatin-28. Mol. Pharmacol. 45, 417-427.

Patel, Y.C., Panetta, R., Escher, E., Greenwood, M., Srikant, C.B., 1994. Expression of multiple somatostatin receptor genes in AtT-20 cells. Evidence for a novel somatostatin-28 selective receptor subtype. J. Biol. Chem. 269, 1506-1509.

Pearson, D., Shively, J.E., Clark, B.R., Gerchwind, I.I., Barkley, M., Nishioka, R.S., Bern, H.A., 1980. Urotensin II: a somatostatin-like peptide in the caudal neurosecretory system of fishes. Proc. Natl. Acad. Sci. USA 77, 5021-5024.

Plisetskaya, E.M., Pollock, H.G., Rouse, J.B., Hamilton, J.W., Kimmel, J.R., Andrews, P.C., Gorbman, A., 1986. Characterization of Coho salmon (Oncorhynchus kisutch) islet somatostatins. Gen. Comp. Endocrinol. 63, 252-263.

Popovici, C., Leveugle, M., Birnbaum, D., Coulier, F., 2001. Coparalogy: physical and functional clusterings in the human genome. Biochem. Biophys. Res. Commun. 288, 362-370 .

Pradayrol, L., Jornvall, H., Mutt, V., Ribet, A., 1980. N-terminally extended somatostatin: the primary structure of somatostatin-28. FEBS Lett. 109, 55-58.

Puebla, L., Mouchantaf, R., Sasi, R.,

Khare, S., Bennett, H.P.J., James, S., Patel, Y.C., 1999. Processing of Rat Preprocortistatin in Mouse AtT-20 Cells. J. Neurochem. 73, 1273-1277. 
Ramirez, J.L., Mouchantaf, R., Kumar, U., Otero-Corchon, V., Rubinstein, M., Low, M.J., Patel, Y.C., 2002. Brain somatostatin receptors are up-regulated in somatostatin-deficient mice. Mol. Endocrinol. 16, 1951-1963.

Robas, N., Mead, E., Fidock, M., 2003. MrgX2 is a high potency cortistatin receptor expressed in dorsal root ganglion. J. Biol. Chem. 278, 44400-44404.

Schally, A.V., Dupont, A., Arimura, A., Redding, T.W., Nishi, N., Lithicum, G.L., Schlesinger, D.H., 1976. Isolation and structure of somatostatin from porcine hypothalami. Biochemistry 15, 509-514.

Sekiguchi, T., Kawashima, T., Satou, Y., Satoh, N., 2007. Further EST analysis of endocrine genes that are preferentially expressed in the neural complex of Ciona intestinalis: receptor and enzyme genes associated with endocrine system in the neural complex. Gen. Comp. Endocrinol. 150, 233-245.

Shen, L.P., Pictet, R.L., Rutter, W.J., 1982. Human somatostatin I: sequence of the cDNA. Proc. Natl. Acad. Sci. USA 79, 4575-4579.

Shen, L.P., Rutter, W.J., 1984., Sequence of the human somatostatin gene. Science 224, 168171.

Sherwood, N.M., Krueckl, S.L., McRory, J.E., 2000. The origin and function of the pituitary adenylate cyclase-activating polypeptide (PACAP)/glucagon superfamily. Endocr. Rev. 21, 619-670.

Siehler, S., Seuwen, K., Hoyer, D., 1998. $\left[{ }^{125} \mathrm{I}\right] \mathrm{Tyr}^{10}{ }^{-}$-cortistatin14 labels all five somatostatin receptors. Naunyn Schmiedebergs Arch. Pharmacol. 357, 483-489.

Slagter, B.J., Sheridan, M.A., 2004. Differential expression of two somatostatin receptor subtype 1 mRNAs in rainbow trout (Oncorhynchus mykiss). J. Mol. Endocrinol. 32, 165-177.

Sower, S.A., Chiang, Y.C., Conlon, J.M., 1994. Polygenic expression of somatostatin in lamprey. Peptides 15, 151-154.

Spier, A.D., de Lecea, L., 2000. Cortistatin: a member of the somatostatin neuropeptide family with distinct physiological functions. Brain. Res. Rev. 33, 228-241. 
Spier, A.D., Fabre, V., de Lecea, L., 2005. Cortistatin radioligand binding in wild-type and somatostatin receptor-deficient mouse brain. Regul. Pept. 124, 179-186.

Spiess, J., Rivier, J.E., Rodkey, J.A., Bennett, C.D., Vale, W., 1979. Isolation and characterization of somatostatin from pigeon pancreas. Proc. Natl. Acad. Sci. USA 76, 2974-2978.

Su, C.J., White, J.W., Li, W.H., Luo, C.C., Frazier, M.L., Saunders, G.F., Chan, L., 1988.

Structure and evolution of somatostatin genes. Mol. Endocrinol. 2, 209-216.

Sugo, T., Murakami, Y., Shimomura, Y., Harada, M., Abe, M., Ishibashi, Y., Kitada, C., Miyajima, N., Suzuki, N., Mori, M., Fujino, M., 2003. Identification of urotensin IIrelated peptide as the urotensin II-immunoreactive molecule in the rat brain. Biochem. Biophys. Res. Commun. 310, 860-868.

Takami, M., Reeve, J.R., Hawke, D., Shively, J.E., Basinger, S., Yamada T., 1985.

Purification of somatostatin from frog brain: coisolation with retinal somatostatin-like immunoreactivity. J. Neurochem. 45, 1869-1874.

Tal, M., Ammar, D.A., Karpuj, M., Krizhanovsky, V., Naim, M., Thompson, D.A., 1995. A novel putative neuropeptide receptor expressed in neural tissue, including sensory epithelia. Biochem. Biophys. Res. Commun. 209, 752-759.

Tavianini, M.A., Hayes, T.E., Magazin, M.D., Minth, C.D., Dixon, J.E., 1984. Isolation, characterization, and cDNA sequence of the rat somatostatin gene. J. Biol. Chem. 259, 11798-11803.

Tostivint, H., Lihrmann, I., Bucharles, C., Vieau, D., Coulouarn, Y., Fournier, A., Conlon, J.M., Vaudry, H., 1996. Occurrence of two somatostatin variants in the frog brain: characterization of the cDNAs, distribution of the mRNAs, and receptor-binding affinities of the peptides. Proc. Natl. Acad. Sci. USA 93, 12605-12610.

Tostivint, H., Trabucchi, M., Vallarino, M., Conlon, J.M., Lihrmann, I., Vaudry, H., 2004a. Molecular evolution of somatostatin genes. In: Srikant, C.B. (Ed.), Somatostatin. Kluwer, Academic Publishers, pp. 47-64. 
Tostivint, H., Joly, L., Lihrmann, I., Ekker, M., Vaudry, H., 2004b. Chromosomal localization of three somatostatin genes in zebrafish. Evidence that the $\left[\mathrm{Pro}^{2}\right]$ somatostatin-14 isoform and cortistatin are encoded by orthologous genes. J. Mol. Endocrinol. 33, R1-R8.

Tostivint, H., Joly, L, Lihmann, I., Parmentier, C., Lebon, A., Morillon, M., Calas, A., Ekker, M., Vaudry, H., 2006. Comparative genomics provides evidence for close evolutionary relationships between the urotensin II and somatostatin gene families. Proc. Natl. Acad. Sci. USA 103, 2237-2242.

Trabucchi, M., Tostivint, H., Lihrmann, I., Jegou, S., Vallarino, M., Vaudry, H., 1999. Molecular cloning of the cDNAs and distribution of the mRNAs encoding two somatostatin precursors in the African lungfish Protopterus annectens. J. Comp. Neurol. 410, 643-652.

Trabucchi, M., Tostivint, H., Lihrmann, I., Sollars, C., Vallarino, M., Dores, R.M., Vaudry, H., 2002. Polygenic expression of somatostatin in the sturgeon Acipenser transmontanus: Molecular cloning and distribution of the mRNAs encoding two somatostatin precursors. J. Comp. Neurol. 443, 332-345.

Trabucchi, M., Tostivint, H., Lihrmann, I., Blähser, S., Vallarino, M., Vaudry, H., 2003.

Characterization of the cDNA encoding a somatostatin variant in the chicken brain: Comparison of the distribution of the two somatostatin precursor mRNAs. J. Comp. Neurol. 461, 441-451.

Travis, G.H., Sutcliffe, J.G., 1988. Phenol emulsion-enhanced DNA-driven subtractive cDNA cloning: isolation of low-abundance monkey cortex-specific mRNAs. Proc. Natl. Acad. Sci. USA 85, 1696-1700.

Uesaka, T., Yano, K., Yamasaki, M., Ando, M., 1995. Somatostatin-, vasoactive intestinal peptide-, and granulin-like peptides isolated from intestinal extracts of goldfish, Carassius auratus. Gen. Comp. Endocrinol. 99, 298-306.

Van de Peer, Y., 2004. Computational approaches to unveiling ancient genome duplications.

Nat. Rev. Genet. 5, 752-763. 
Vaudry, D., Gonzalez, B.J., Basille, M., Yon, L., Fournier, A., Vaudry, H., 2000. Pituitary adenylate cyclase-activating polypeptide and its receptors: from structure to functions. Pharmacol. Rev. 52, 269-324.

Vaudry, H., Chartrel, N., Conlon, J.M., 1992. Isolation of $\left[\mathrm{Pro}^{2}, \mathrm{Met}^{13}\right]$ somatostatin-14 and somatostatin-14 from the frog brain reveals the existence of a somatostatin gene family in a tetrapod. Biochem. Biophys. Res. Commun. 188, 477-482.

Veber, D.F., Holly, F.W., Nutt, R.F., Bergstrand, S.J., Brady, S.F., Hirschmann, R., Glitzer, M.S., Saperstein, R., 1979. Highly active cyclic and bicyclic somatostatin analogues of reduced ring size. Nature 280, 512-514.

Wang, Y., Conlon, J.M., 1993a. Neuroendocrine peptides (NPY, GRP, VIP, somatostatin) from the brain and stomach of the alligator. Peptides 13, 573-579.

Wang, Y., Youson, J.H., Conlon, J.M., 1993b. Prosomatostatin-I is processed to somatostatin-26 and somatostatin-14 in the pancreas of the bowfin, Amia calva. Regul. Pept. 47, 33-39.

Wang, Y., Nielsen, P.F., Youson, J.H., Potter, I.C., Conlon, J.M., 1999a. Multiple forms of glucagon and somatostatin isolated from the intestine of the southern-hemisphere lamprey Geotria australis. Gen. Comp. Endocrinol. 113, 274-282.

Wang, Y., Lance, V.A., Nielsen, P.F., Conlon, J.M., 1999b. Neuroendocrine peptides (insulin, pancreatic polypeptide, neuropeptide $\mathrm{Y}$, galanin, somatostatin, substance $\mathrm{P}$, and neuropeptide $\gamma$ ) from the desert tortoise, Gopherus agassizii. Peptides 20, 713-722.

Xing, Y., Wensheng, L., Haoran, L., 2005. Polygenic expression of somatostatin in orangespotted grouper (Epinephelus coioides): molecular cloning and distribution of the mRNAs encoding three somatostatin precursors. Mol. Cell. Endocrinol. 241, 62-72.

Yunker, W.K., Smith, S., Graves, C., Davis, P.J., Unniappan, S., Rivier, J.E., Peter, R.E., Chang, J.P., 2003. Endogenous hypothalamic somatostatins differentially regulate growth hormone secretion from goldfish pituitary somatotropes in vitro. Endocrinology 144, 4031-4041. 


\section{Legends to figures}

Fig. 1. Alignment of the amino acid sequences of prepro-somatostatin 1-derived peptides. Conserved residues are in bold characters.

Fig. 2. Alignment of the amino acid sequences of prepro-somatostatin 2- / preprocortistatin-derived peptides. Conserved residues are in bold characters. The $\mathrm{Pro}^{2}$ residue that is characteristic of SS2 is boxed.

Fig. 3. Alignment of the amino acid sequences of prepro-somatostatin 3- (previously designated prepro-somatostatin II-) derived peptides. Conserved residues are in bold characters. Characteristic residues of SS3 are boxed.

Fig. 4. Alignment of the amino acid sequences of prepro-somatostatin 4- (previously designated atypical prepro-somatostatin II-) derived peptides. Conserved residues are in bold characters. Characteristic residues of SS4 are boxed.

Fig. 5. Alignment of the amino acid sequences of other somatostatin-related peptides. Conserved residues are in bold characters. Characteristic residues of these variants are boxed.

Fig. 6. Comparison of the amino acid sequences and predicted secondary structures of somatostatin 1 (SS1) and Drosophila allatostatin C (AllC).

Fig. 7. Map showing chromosomal positions of the somatostatin 2 (SS2) gene in zebrafish and the cortistatin (CST) gene in human. A conserved synteny on zebrafish linkage group 23 (LG23) and human 1p36 can be observed. All distances, expressed in Mb, were retrieved from Ensembl. The chromosome locations of the zebrafish genes were taken from the $7^{\text {th }}$ 
assembly (version Zv7) of the zebrafish genome, released on July 13, 2007. CTNNBIP1, catenin beta-interacting protein 1; HKR3, Homo sapiens GLI-Kruppel family member 3; MASP, mannose-binding lectin-associated serine protease; PGD, phosphogluconate dehydrogenase; TARDBP, TAR DNA binding protein; SDR1, short-chain dehydrogenase/reductase 1 .

Fig. 8. Map showing chromosomal positions of the genes encoding somatostatin 1 (SS1), cortistatin (CST), urotensin II (UII) and urotensin II-related peptide (URP) in human. A conserved synteny on $1 \mathrm{p} 36$ and 3q28 can be observed. All distances, expressed in $\mathrm{Mb}$, are taken from Ensembl. CLCN, chloride channel; MASP, mannose-binding lectin-associated serine protease; TP73, tumor protein 73; TP73L, tumor protein 73-like; UII, urotensin II; URP, urotensin II-related peptide.

Fig. 9. Map showing chromosomal positions of the genes encoding somatostatin 1 (SS1), somatostatin 3 (SS3; previously designated SSII) and somatostatin 4 (SS4; previously designated atypical SSII) in zebrafish. All distances, expressed in Mb, were taken from the Ensembl database, version Zv7.

Fig. 10. Comparison of the amino acid sequences and predicted secondary structures of somatostatin 1 (SS1), goby urotensin II (UII) and mammalian urotensin II-related peptide (URP).

Fig. 11. Proposed gene duplication scheme for the SS/UII superfamily. The crossed-through genes were probably lost after duplication events. SS, somatostatin; CST, cortistatin; UII, urotensin II; URP, urotensin II-related peptide. $\alpha$ and $\beta$ isoforms designate variant genes that occur in some teleost species which probably arose from the fish-specific tetraploidization event. So far, only one copy of the URP gene has been identified, suggesting that the second 
copy has been lost during teleost evolution. The origin of the SS4 gene (previously designated atypical SSII gene) is currently unknown. 
Cow

Elephant

Hedgehog

Human, chimpanzee

Macaque

Mouse

Rabbit

Rat

Tree shrew

Opossum

Platypus

Chicken

Frog

Lungfish

Fugu, tetraodon

Medaka, stickleback

Zebrafish, goldfish

Sturgeon

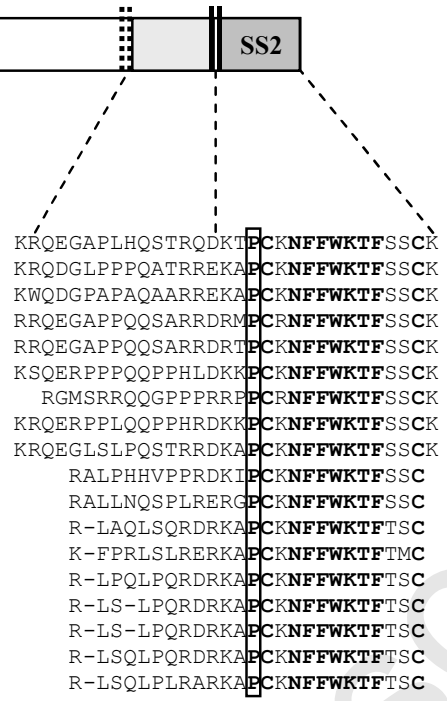

Figure 2 


\author{
Anglerfish \\ Arawana \\ Butterfly fish \\ Eel \\ Flounder \\ Fugu \\ Goldfish \\ Goldfish' \\ Grouper \\ Medaka \\ Sculpin \\ Tilapia \\ Trout \\ Salmon, trout' \\ Zebrafish
}

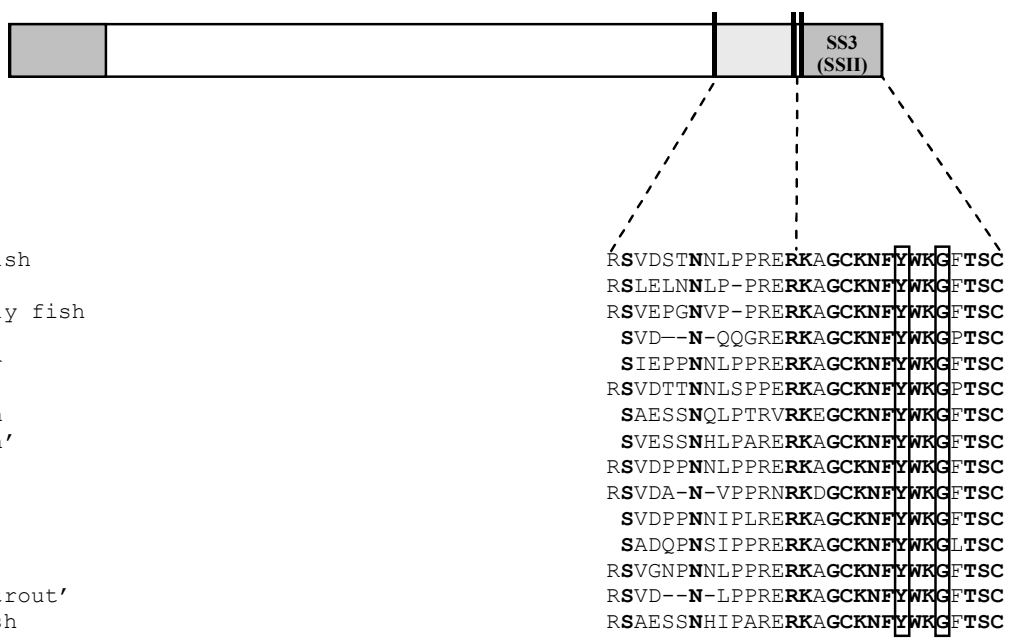

Figure 3 


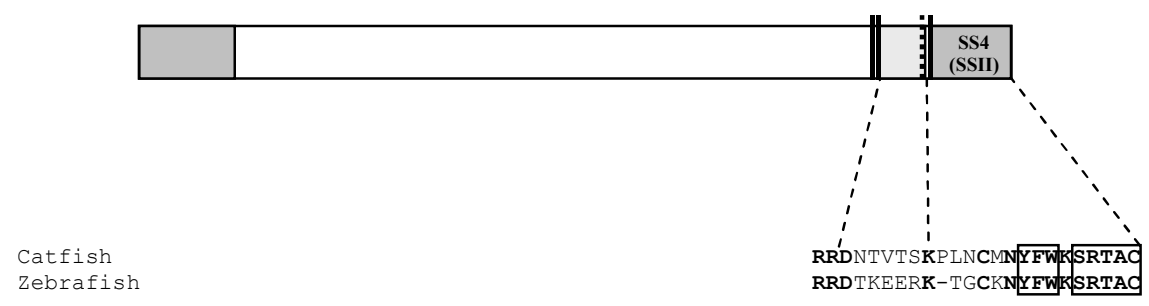

Figure 4 
Sea lamprey

River lamprey

Southern-hemisphere lamprey

Ratfish

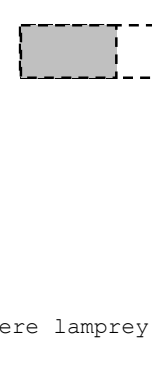

SS

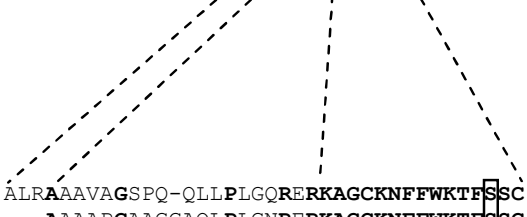

AAAAPGAAGGAQLPLGNRERKAGCKNFFWKTE SSC

AVQEAGGA--AMP PPGQRDRKAGCKNFFWKTESSC

AGCKSFFWKTFTSC

Figure 5 
Table 5 .

Characterization of the sequences of other somatostatin-related peptides

$$
\text { Species }
$$

Source

River lamprey, Lampetra fluviatilis

Sea lamprey, Petromyzon marinus

Southern-hemisphere lamprey, Geotria australis

Pacific ratfish, Hydrolagus colliei

References

Conlon et al., 1995a

Andrews et al., 1988

Conlon et al., 1995b

$\mathrm{P}$, sequences were determined from peptides. 


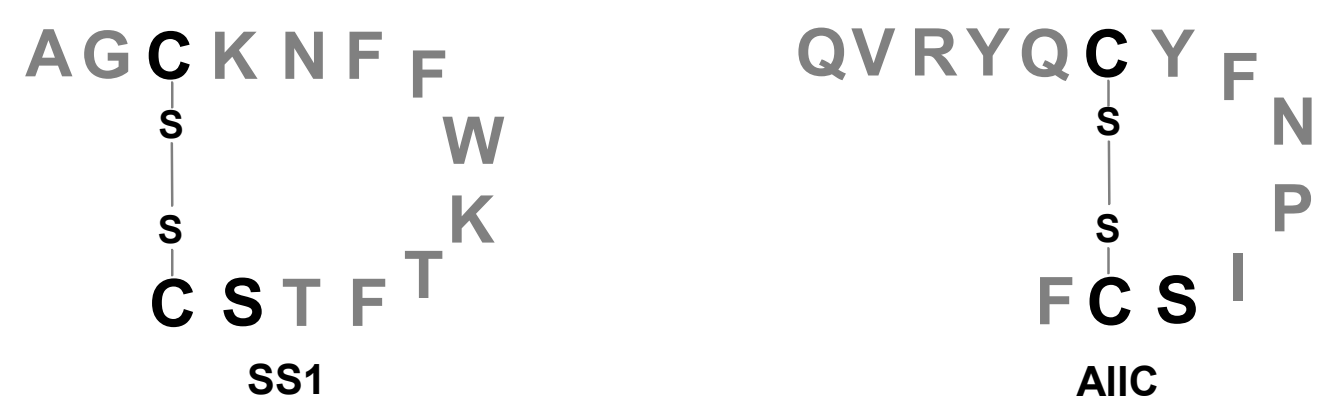

Figure 6 


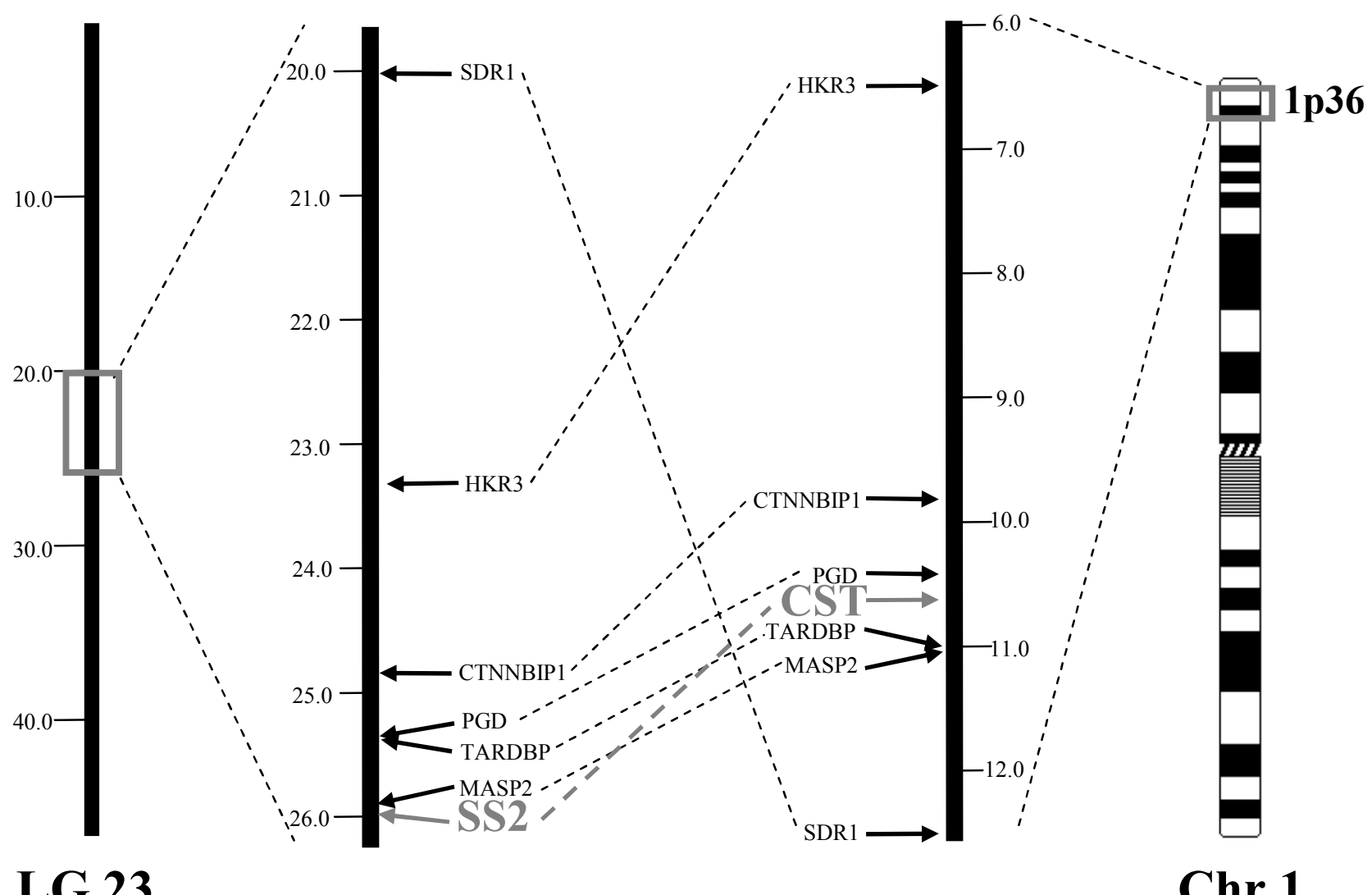

Figure 7 


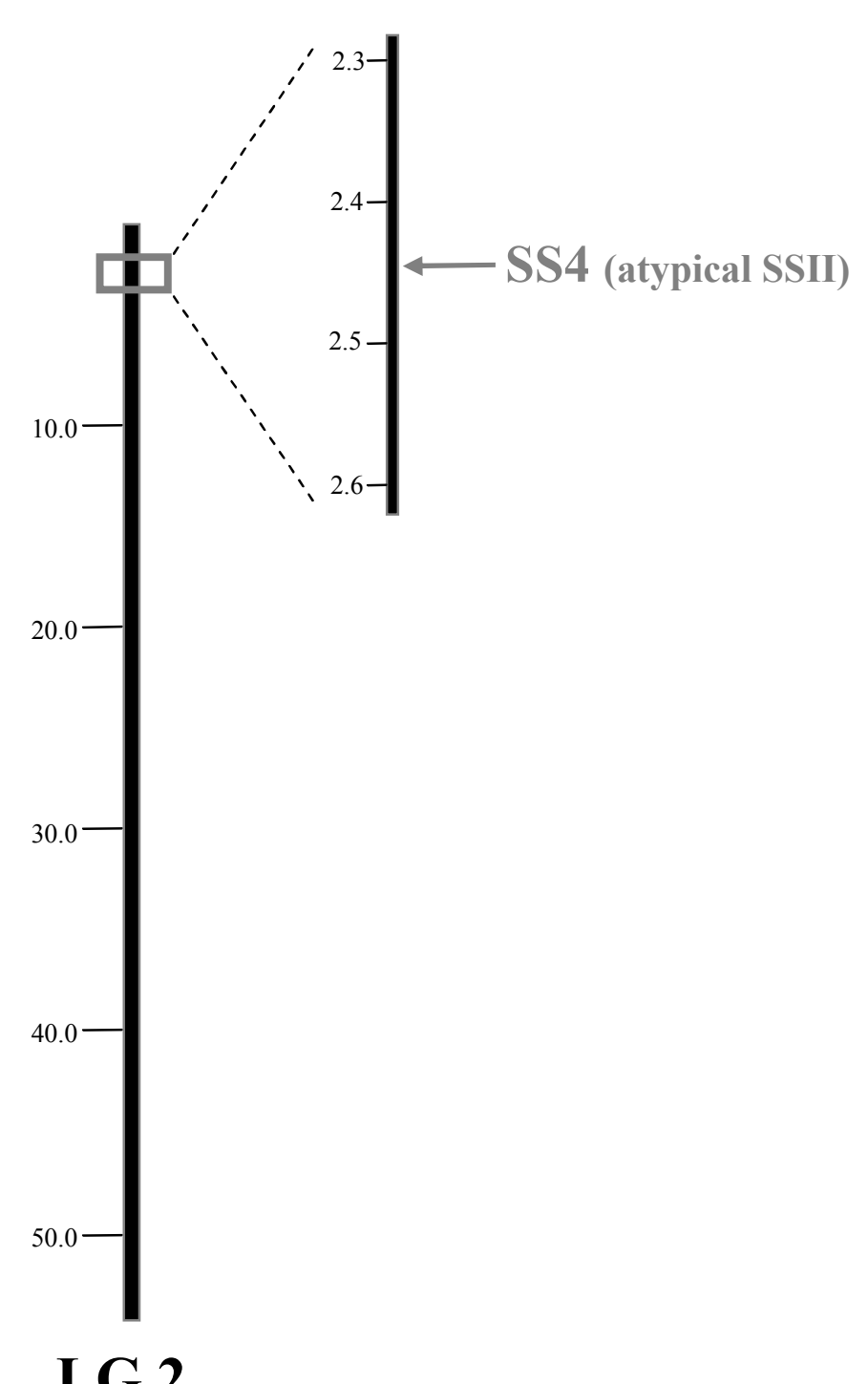

LG 2

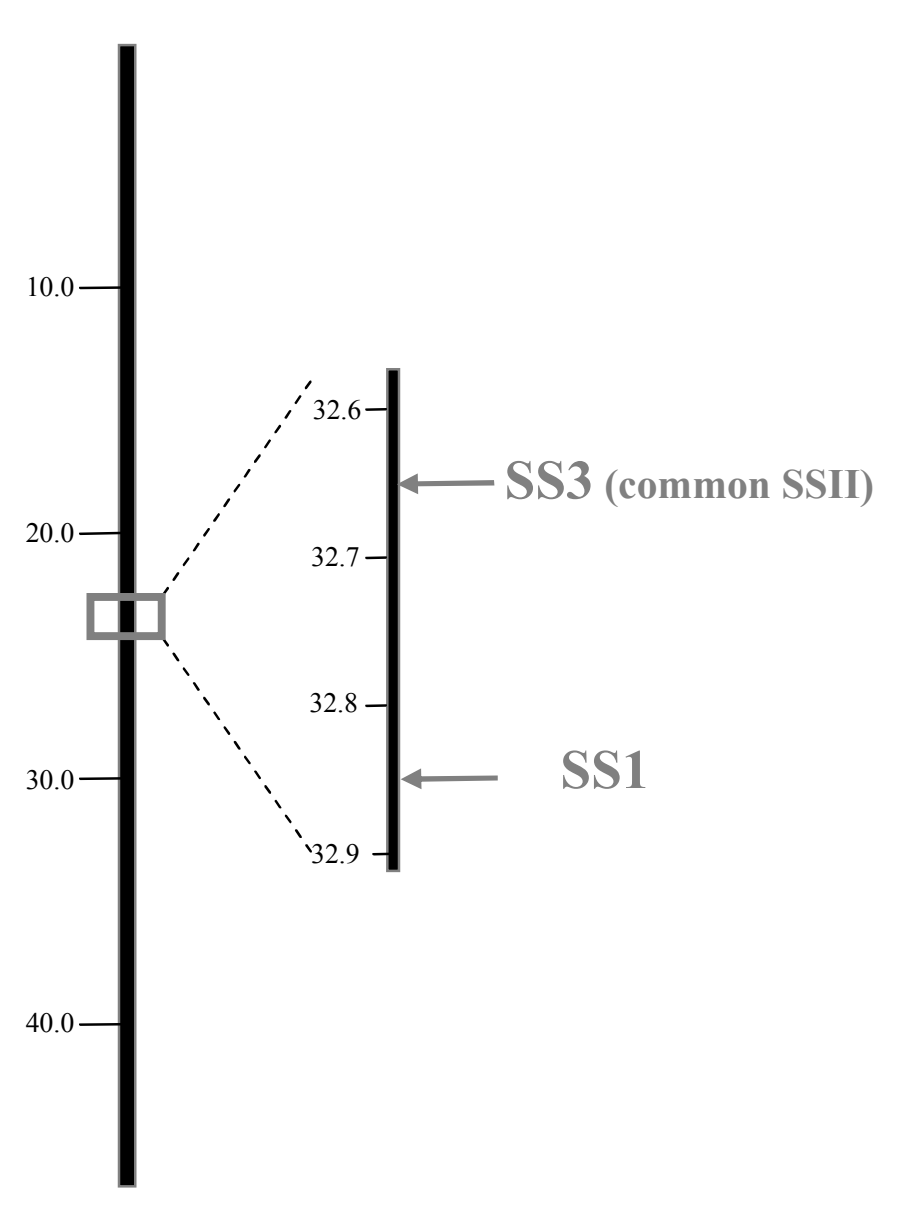

LG 15

Figure 9 

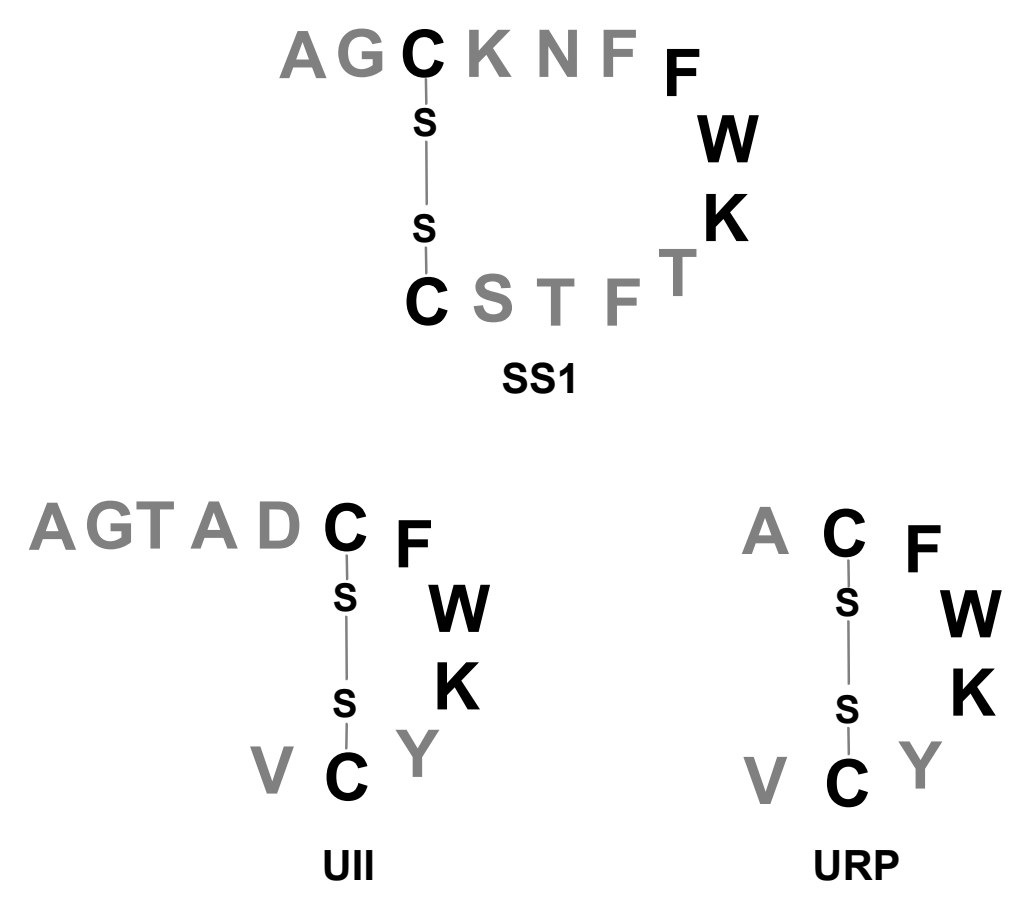


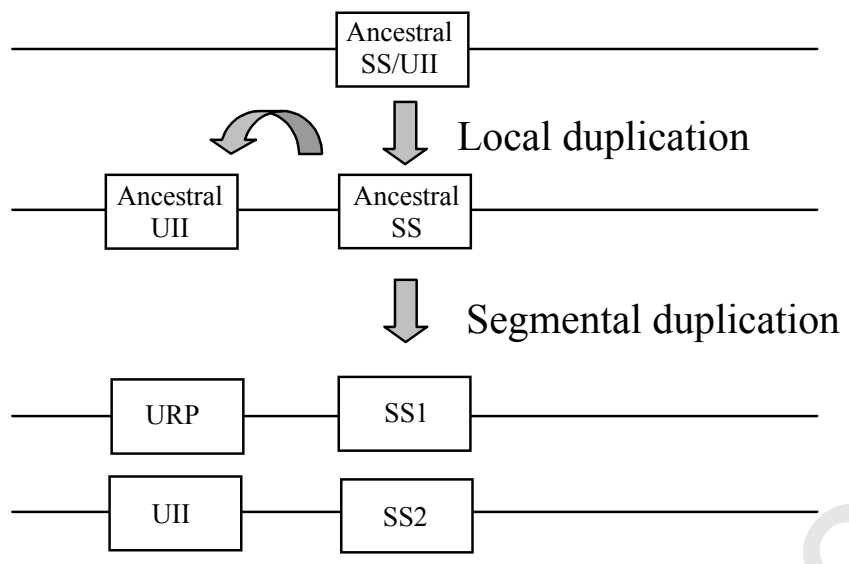

Tetrapod lineage $\searrow$ Ray-finned fish lineage

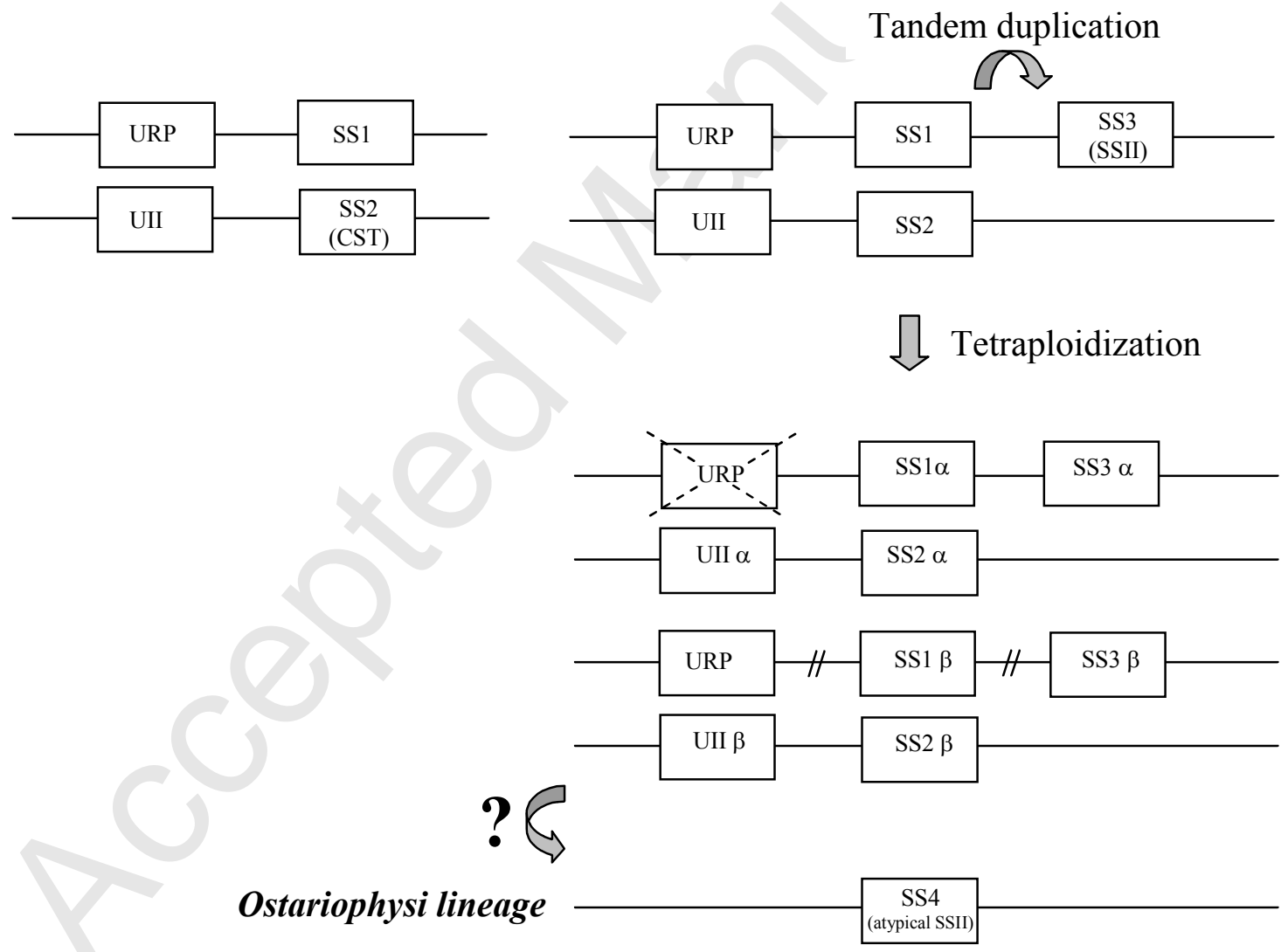

Figure 11 


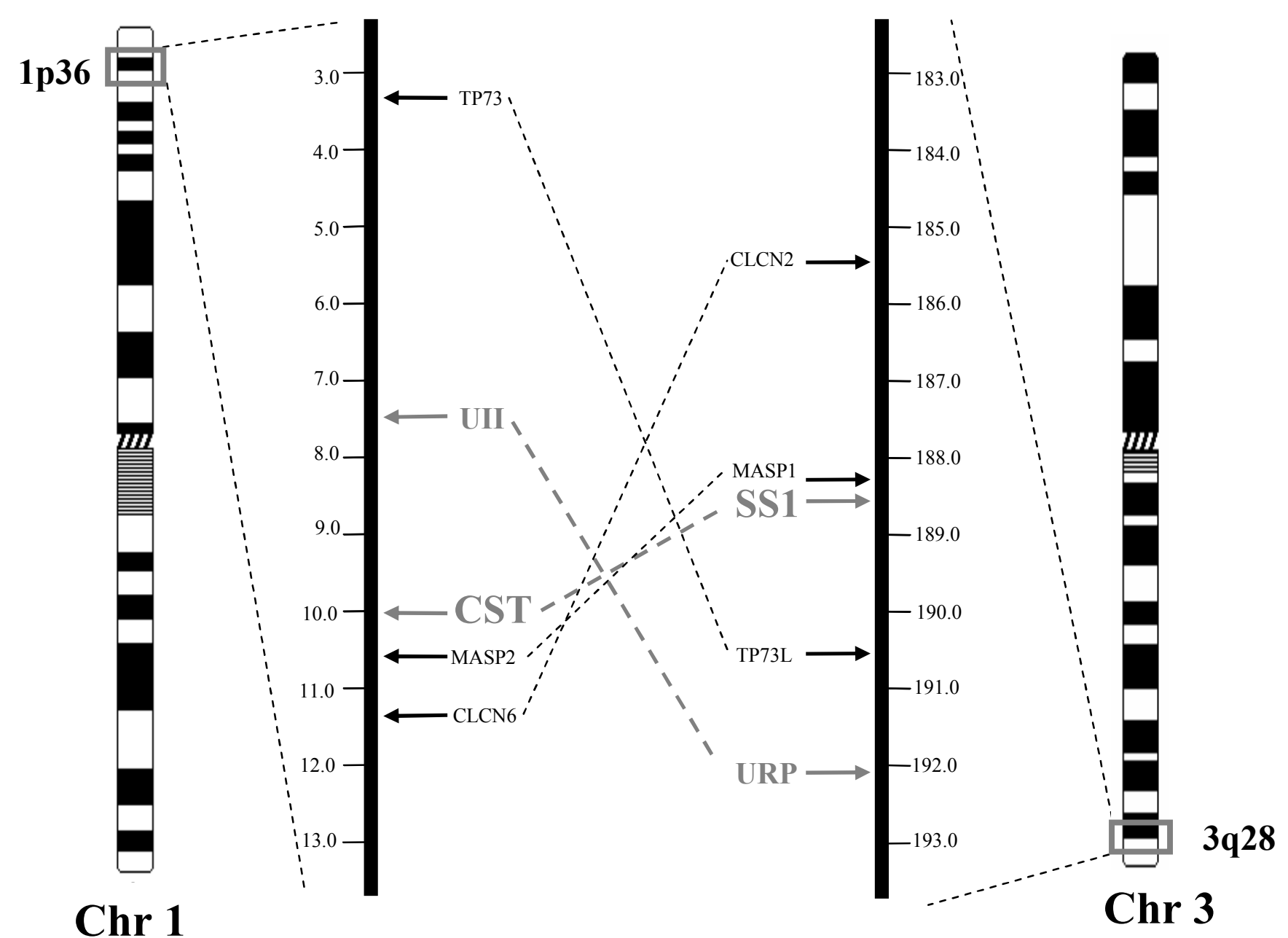

Figure 8 
Table 4.

Characterization of the sequences of somatostatin 4 (previously designated atypical somatostatin II) in teleosts

Species Source References

Catfish, Ictalurus punctatus $\mathrm{P}$

Pacu, Piaractus mesopotamicus

Zebrafish, Danio rerio

Magazin et al., 1982

Ferraz de Lima et al., 1999

$\begin{array}{ll}\mathrm{P} & \text { Ferraz de Lima et al., } \\ \mathrm{C} & \text { Argenton et al., } 1999\end{array}$

W (Chr.2) (DS) ENSDARG00000014190

Sequences determined from: P, peptides; C, cDNA; W, whole genomes (chromosome localization).

DS, direct submission (Ensembl). 
Table 3 .

Characterization of the sequences of somatostatin 3 (previously designated somatostatin II) in teleosts

Species

Anglerfish, Lophius americanus

Freshwater butterflyfish, Pantodon buchholzi

Coho salmon, Onchorhynchus kisutch

Daddy Sculpin, Cottus scorpius

Eel, Anguilla anguilla

Flounder, Platichtythes flesus

Fugu, Takifugu rubripes

Goldfish, Carassius auratus

Medaka, Oryzias latipe

Orange spotter grouper, Epinephelus coioides

Silver arawana, Osteoglossum bicirrhosum

Tilapia, Oreochromis nilotica

Trout, Oncorhynchus mykiss

Zebrafish, Danio rerio

\section{References}

Hobart et al., 1980

Andrews et al.,, 1984

(DS2) AF292651

Plisetskaya et al., 1986

Conlon et al., 1987

Conlon et al., 1988 a

Conlon et al., 1987

(DS) SINFRUG00000161986

Uesaka et al., 1995

Lin et al., 1999b

(DS) ENSORLG00000019158

Xing et al., 2005

(DS2) AF292650

Nguyen et al., 1995

Sequences determined from: $\mathrm{P}$, peptides; $\mathrm{C}, \mathrm{cDNA} ; \mathrm{W}$, whole genomes (chromosome localization) $\mathrm{DS}$, direct submission (Ensembl). 
Table 2.

Characterization of the sequences of somatostatin $2 /$ cortistatin

Species

Chimpanzee, Pan troglodytes

ource

References

Cow, Bos taurus

Hedgehog, Echinops telfairi

Human, Homo sapiens

Macaque, Macaca mulatta

Mouse, Mus musculus

Rabbit, Oryctolagus cuniculus

Rat, Rattus norvegicus

Opossum, Monodelphis domestica

Platypus, Ornithorhynchus anatinus

Chicken, Gallus gallus

European green frog, Rana ridibunda

African lungshish, Protopterus annectens

Fugu, Takifugu rubripes

Goldfish, Carassius auratus

Medaka, Oryzias latipes

Orange spotter grouper, Epinephelus coioides

Tetraodon, Tetraodon nigroviridis

Zebrafish, Danio rerio

Russian sturgeon, Acipenser gueldenstaedti

White sturgeon, Acipenser transmontanus

$\begin{array}{ll}\text { Source } & \text { References } \\ \text { W (Chr.1) } & \text { (DS) ENSPTRG00000000130 } \\ \text { W(Chr.16) } & \text { (DS) ENSBTAG00000013531 } \\ \text { W } & \text { (DS)ENSLAFG00000009597 } \\ \text { W } & \text { (DS)ENSETEG00000000662 } \\ \text { C } & \text { Fukusumi et al., 1997; de Lecea et al., 1997 } \\ \text { W (Chr.1) } & \text { (DS) ENSG00000175279 } \\ \text { W } & \text { (DS) ENSMMUG00000023030 } \\ \text { C } & \text { De Lecea et al., 1997 } \\ \text { G } & \text { Calbet et al., 1999 } \\ \text { W (Chr.4) } & \text { (DS) ENSMUSG00000028971 } \\ \text { W } & \text { (DS) ENSOCUG00000017682 } \\ \text { C } & \text { De Lecea et al., 1996 } \\ \text { W } & \text { (DS) ENSMODG00000002663 } \\ \text { W } & \text { (DS) ENSOANG00000002799 } \\ \text { C } & \text { Trabucchi et al., 2003 } \\ \text { W (Chr. 21) } & \text { (DS) ENSGALG00000003034 } \\ \text { P } & \text { Vaudry et al., 1992 } \\ \text { C } & \text { Tostivint et al., 1996 } \\ \text { C } & \text { Trabucchi et al., 1999 } \\ \text { W } & \text { (DS) SINFRUG00000143244 } \\ \text { C } & \text { Lin et al., 1999b } \\ \text { W } & \text { (DS) ENSORLG00000005136 } \\ \text { C } & \text { Xing et al., 2005 } \\ \text { W (Chr.9) } & \text { (DS) GSTENG00028263001 } \\ \text { W (Chr.23) } & \text { (DS) ENSDARG00000031649 } \\ \text { P } & \text { Nishii et al., 1995 } \\ \text { C } & \text { Trabucchi et al., 2002 } \\ & \end{array}$

Sequences determined from: P, peptides; C, cDNA; W, whole genomes (chromosome localization).

DS, direct submission (Ensembl). 
Table 1.

Characterization of the sequences of somatostatin 1 in vertebrates

\begin{tabular}{|c|c|c|}
\hline Species & Source & References \\
\hline Armadillo, Dasypus novemcinctus & $\mathrm{W}$ & (DS1) ENSDNOG00000013697 \\
\hline Cat, Felis catus & W & (DS1) ENSFCAG00000006706 \\
\hline Chimpanzee, Pan troglodytes & W(Chr.3) & (DS1) ENSPTRG00000015727 \\
\hline \multirow[t]{3}{*}{ Cow, Bos taurus } & $\mathrm{C}$ & Su et al., 1988 \\
\hline & G & Furu et al., 1999 \\
\hline & W (Chr.1) & (DS1) ENSBTAG00000017312 \\
\hline Dog Canis familiaris & W (Chr.34) & (DS1) ENSCAFG00000013891 \\
\hline Elephant, Loxodonta africana & W & (DS1) ENSLAFG00000012303 \\
\hline \multirow[t]{2}{*}{ Guinea pig, Cavia porcellus } & $P$ & Conlon, 1984 \\
\hline & W & (DS1) ENSCPOG00000009662 \\
\hline Hedgehog, Echinops telfairi & W & (DS1) ENSETEG00000014520 \\
\hline Hedgehog, Erinaceus europaeus & W & (DS1) ENSEEUG00000006120 \\
\hline \multirow[t]{4}{*}{ Human, Homo sapiens } & $\mathrm{P}$ & Conlon and McCarthy, 1984 \\
\hline & $\mathrm{C}$ & Shen et al., 1982 \\
\hline & G & Shen and Rutter, 1984 \\
\hline & W (Chr.3) & (DS1) ENSG00000157005 \\
\hline Macaque, Macaca fascicularis & $\mathrm{C}$ & Travis and Sutcliffe, 1988 \\
\hline Macaque, Macaca mulatta & W (Chr.2) & (DS1) ENSMMUG00000000850 \\
\hline \multirow[t]{3}{*}{ Mouse, Mus musculus } & $\mathrm{C}$ & (DS2) NM_009215 \\
\hline & G & Fuhrmann et al., 1990 \\
\hline & W (Chr.16) & (DS1) ENSMUSG00000004366 \\
\hline \multirow{2}{*}{ Pig, Sus scrofa } & $\mathrm{P}$ & Schally et al., 1976 \\
\hline & $\mathrm{C}$ & (DS2) NM_001009583 \\
\hline Rabbit, Oryctolagus cuniculus & $\mathrm{W}$ & (DS1) ENSOCUG00000007564 \\
\hline \multirow[t]{4}{*}{ Rat, Rattus norvegicus } & $\mathrm{P}$ & Bohlen et al., 1981 \\
\hline & $\mathrm{C}$ & Funckes et al., 1983; Goodmann et al., 1982 \\
\hline & G & Montminy et al., 1984; Tavianini et al., 1984 \\
\hline & W (Chr.11) & (DS1) ENSRNOG00000001837 \\
\hline \multirow[t]{2}{*}{ Sheep, Ovis aries } & $\mathrm{P}$ & Brazeau et al., 1973 \\
\hline & $\mathrm{C}$ & Bruneau and Tillet, 1998 \\
\hline Tree Shrew, Tupaia belangeri & W & (DS1) ENSTBEG00000009329 \\
\hline Opossum, Monodelphis domestica & W & (DS1) ENSMODG00000008503 \\
\hline Platypus, Ornithorhynchus anatinus & W & (DS1) ENSOANG00000000871 \\
\hline \multirow{2}{*}{ Chicken, Gallus gallus } & $\mathrm{C}$ & (DS2) NM_205336; X60191 \\
\hline & W (Chr. 9) & (DS1) ENSGGALG00000007361 \\
\hline Pigeon, Colomba livia & $\mathrm{P}$ & Spiess et al., 1979 \\
\hline Alligator, Alligator mississipiensis & $\mathrm{P}$ & Wang and Conlon, 1993a \\
\hline Python, Python molurus & $\mathrm{P}$ & Conlon et al., 1997b \\
\hline Red-eared slider turtle, Trachemys scripta & $P$ & Conlon and Hicks, 1990 \\
\hline Tortoise, Gopherus agassizii & $\mathrm{P}$ & Wang et al., $1999 \mathrm{~b}$ \\
\hline Amphiuma, Amphiuma tridactylum & $\mathrm{P}$ & Cavanaugh et al., 1996 \\
\hline European green frog, Rana ridibunda & $P$ & Vaudry et al., 1992 \\
\hline & $\mathrm{C}$ & Tostivint et al., 1996 \\
\hline Leopard frog, Rana pipens & $\mathrm{P}$ & Takami et al., 1985 \\
\hline Toad, Xenopus laevis & $\mathrm{C}$ & (DS1) AY316318 (a); AY319522 (b) \\
\hline & $\mathrm{W}$ & (DS1)ENSXETG00000014247; ENSXETG00000019777 \\
\hline African lungfish, Protopterus annectens & $\mathrm{C}$ & Trabucchi et al., 1999 \\
\hline Anglerfish, Lophius americanus & $\mathrm{P}$ & Noe et al., 1979 \\
\hline & $\mathrm{C}$ & Hobart et al., 1980 \\
\hline Catfish, Ictalurus punctatus & $\mathrm{C}$ & Minth et al., 1982 \\
\hline Clown knifefish, Chitala chitala & $\mathrm{C}$ & (DS2) AF292653 \\
\hline Coho salmon, Onchorhynchus kisutch & $P$ & Plisetskaya et al., 1986 \\
\hline Daddy sculpin, Cottus scorpius & $P$ & Conlon et al., 1987 \\
\hline Eel, Anguilla anguilla & $P$ & Conlon et al., 1988a \\
\hline European flounder, Platichtythes flesus & $\mathrm{P}$ & Conlon et al.,1987 \\
\hline Goldfish, Carassius auratus & $\mathrm{C}$ & Lin et al., 1999b \\
\hline Medaka, Oryzias latipes & $\mathrm{W}$ & (DS1) ENSORLG00000019152 \\
\hline Megalobrama, Megalobrama pellegrini & $\mathrm{C}$ & (DS2) AY247267 \\
\hline Orange spotter grouper Epinephelus coioides & $C$ & Xing et al., 2005 \\
\hline Pacu, Piaractus mesopotamicus & $\mathrm{P}$ & Ferraz de Lima et al., 1999 \\
\hline Stickleback, Gasterosteus aculeatus & $\mathrm{W}$ & (DS1) ENSGACG00000004479 \\
\hline Stone flounder, Kareius bicoloratus & $P$ & Andoh and Nagasawa, 1998 \\
\hline Tetraodon, Tetraodon nigroviridis & $\mathrm{W}$ & (DS1) GSTENG00021180001 \\
\hline Tilapia, Oreochromis nilotica & $P$ & Nguyen et al., 1995 \\
\hline Trout, Oncorhynchus mykiss & $\mathrm{C}$ & Kittilson et al., 1999 \\
\hline Weakly electric fish, Gnathonemus petersii & $\mathrm{C}$ & (DS2) AF292652 \\
\hline White sucker, Catostomus commersoni & $\mathrm{C}$ & (DS2) AF292654 \\
\hline Zebrafish, Danio rerio & $\mathrm{C}$ & Devos et al., 2002 \\
\hline & W (Chr.15) & (DS1) ENSDARG00000040799 \\
\hline Bowfin, Amia calva & $\mathrm{P}$ & Wang et al., 1993b \\
\hline American paddlefish, Polyodon spathula & $\mathrm{P}$ & Conlon, unpublished data \\
\hline Pallid sturgeon, Scaphirhynchus albus & $\mathrm{P}$ & Kim et al., 2000 \\
\hline White sturgeon, Acipenser transmontanus & $\mathrm{C}$ & Trabucchi et al., 2002 \\
\hline Ray, Torpedo marmorata & $P$ & Conlon et al., 1985 \\
\hline River lamprey, Lampetra fluviatilis & $\mathrm{P}$ & Conlon et al., 1995a \\
\hline Sea lamprey, Petromyzon marinus & $\mathrm{P}$ & Sower et al., 1994 \\
\hline Southern-hemisphere lamprey, Geotria australis & $\mathrm{P}$ & Wang et al., 1999a \\
\hline Hagfish, Myxine glutinosa & $\mathrm{P}$ & Conlon et al., 1988b \\
\hline
\end{tabular}

Hagfish, Myxine glutinosa

Sequences determined from: P, peptides; C, cDNA; G, genes; W, whole genomes (chromosome localization). DS, direct submission (1: Ensembl; 2: GenBank). 
Armadillo

Cat

Human, cow, dog, elephant, monkeys, rabbit, rodents, sheep, etc.. Opossum

Platyopus

Chicken

Frog

Xenopus

Lungfish

Bowfin

Anglerfish

Fugu $\alpha$

Fugu $\beta$

Knifefish

Medaka

Stickleback

Tetraodon

Trout

Zebrafish, catfish, goldfish, megalobrama

Sturgeon

Hagfish

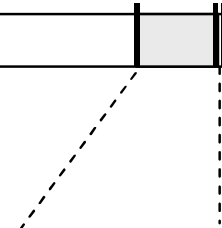

R'--SANTS PAMATRERंKAGCKNFFWKTFTSC̀ R--STNSNPAMAPRERKAGCKNFFWKTFTSC R--SANSNPAMAPRERKAGCKNFFWKTFTSC R--SANSNPAMTTRERKAGCKNFFWKTFTSC R--SANSKPAMTPRERKAGCKTFFWKTFTSC R--SANSNPALAPRERKAGCKNFFWKTFTSC R--SANSSPALAPRERKAGCKNFFWKTFTSC R--SANSSPVLAPRERKAGCKNFFWKTFTSC R--SANSSP-LAARERKAGCKNFFWKTFTSC SAN--PALAPRERKAGCKNFFWKTFTSC R--AASGGPLLAPRERKAGCKNFFWKTFTSC R-AAAAIGPFLTPRERKAGCKNFFWKTFTSC R--Q---VPF-SQRDRKAGCRNFFWKTFTSC R--AA--GPPLAPRERKAGCKNFFWKTFTSC R-AAA-SGPLIAPRDRKAGCKNFFWKTFTSC R-AAA-SGPLLAPRDRKAGCKNFFWKTFTSC
R--AADAGP LLGPRERKAGCKNFFWKTFTSC RAADAGIGP FLTPRERKAGCKNFFWKTFTSC R--AP--GPVLAPRERKAGCKNFFWKTFTSC R--AA--GPMLAPRERKAGCKNFFWKTFTSC R--SANGNPAMAPRERKAGCKNFFWKTFTSC AVERPR--QDGQVHEPPGRERKAGCKNFFWKTFTSC

Figure 1 